\title{
Causality between metal prices: Is joint consumption a more important determinant than joint production of main and by-product metals?
}

\section{Abstract}

Research on metal price determinants has been driven by increasing price volatilities and realization of metals as financial assets. A sound understanding of metal prices enables producers, consumers, policy makers and traders to anticipate and better prepare themselves for short and long-term price trends. Metal prices are related to each other via their nature of either being jointly produced or jointly consumed. While the effects of joint production of metals have been the subject of increased analysis lately, the effects of joint consumption on metal prices have yet to be studied systematically. Therefore, we aim to analyze the effects of both joint consumption and joint production on the causality relationship between metal prices. In doing so, we use the Toda Yamamoto approach to conduct pairwise Granger-causality tests between various metals that are either jointly produced or jointly consumed. Our results indicate that joint-consumption of metals has a significant impact on the Granger-causality relationship between metals and that it is indeed amportant determinant of metal prices.

\section{Introduction}

Over the past few years, commodities Such as metals have been realized as financial assets, with a significant increase in terms of investment and, trading volume over the past years (Frankel, 1986; Lutzenberger et al., 2017). Pair trading (is an example of a trading strategy of metals, in which different positions on two different metals can be taken simultaneously and is a popular strategy among hedge fund traders (Huang Z. and Martin F., 2017). Sound knowledge of metal price behaviors is a prerequisite for effective trading strategies in order to maximize profits in all market conditions. Furthermore, increasing metal prices and volatility has been a constant motivation to analyze the behavior of metal prices, especially for investors and policy makers for their economic planning. For developing countries that rely on metal exports as one of the main sources of income, price fluctuations pose especially a big problem as these lead to fluctuations in national income and uncertainties in macroeconomic management. Diversification is generally seen as an effective way to mitigate possible economic risks and uncertainties related to metal prices. A well-diversified metal portfolio can provide a stabilizing effect on price fluctuations. However, portfolio diversification only effectively works if the related metals in either production or consumption do not react similarly to market information (CPA Australia, 2012). These examples emphasize the need for knowledge on the price dependencies and relationship between various metals to be able to anticipate and be better prepared against price fluctuations and sudden change in the metal market. 
Principally, metals are physically related to each other under two circumstances, namely joint production and joint consumption. Regarding joint production, metals are very often mined together since they consistently occur together in mineral deposits on the Earth's crust. For example, chalcophile elements such as copper, lead and zinc often exist together as sulfide minerals. Similarly, titanium and zirconium also occur together as mineral sand deposits (Rankin, 2011). Metals that are mined together can be categorized into three groups, namely (I) primary metals, (II) by-products and (III) co-products. Primary metals usually have the largest volume of mining and are fundamental to the economic viability of a mine, that its market price determines the mining strategy and ore production of a mine (Tilton and Guzmán, 2016). Primary metals tend to be geographically concentrated in highgrade large deposits (Rankin, 2011), and are also commonly traded on major public exchanges and are fundamental components to industrial applications (Hagelüken and Meskers, 2010). Steel, copper, aluminium, nickel, lead, zinc, gold and silver are examples of metals that are usually considered as primary metals.

The second group of metals is by-products. A metal is considered a by-product if it is a secondary product from a mine and if its price has no influence on the profit-maximizing decision of the production and on the output of the main product (Brooks, 1965). The supply of by-products is limited by two factors, particularly by the output of the primary metal and by the specific operational cost of the by-products. By-products do not share any joint-production costs with the primary metal as these are borne only by the primary metal. Depending on the specific cost, a by-product may be marketable or is considered a waste and is often disposed of (Rankin, 2011; Tilton and Guzmán, 2016). Due to their dependency to primary metals as well as limited producers and field of application, the price volatility of by-product metals tend to be much greater than their respectively primary metals (Redlinger and Eggert, 2016). Bismuth production in lead mines and arsenic production in copper mines are examples of by-products relative to their respective primary metals.

The third group of metals is known as co-products, which can be categorized between primary metals and by-products. Co-products are by-product metals of value that influences the mining strategy and consequently, the ore production (Campbell, 1985). While the by-products do not contain any jointproduction cost, co-products on the other hand, share the joint production costs with the primary metal (Fizaine, 2013; Tilton and Guzmán, 2016). For example, the sizeable amount of molybdenum mined in a copper mine coupled with the relatively higher price than copper makes molybdenum a co-product of copper.

Apart from the joint production of metals, joint consumption is another aspect that relates metals and can be useful in establishing price dependencies among metals. The basic principle is that, if significant amounts of two metals are used in a single product, a demand shock of that product might affect the prices of both metals simultaneously, as the demand and supply equilibrium of both metals will be disrupted. As an example, the effect of joint consumption between crude oil prices was 
analyzed by Coronado et al. (2016). The authors reported strong evidence of causality between daily Brent, West Texas Intermediate (WTI) and Argus oil prices, which can be, among others, attributed to the demand in their common sectors such as vehicles and heating oil. However, the relationship between jointly-consumed metals strongly depends on the level of consumption aggregation. For instance, metals that are used together in a single product are classified as complements in demand, whereas metals that are used in separate products but used for the same applications are considered as substitutes in demand. Under these premises, Brent and WTI are clearly substitutes since they have a competing relationship. However, if one considers all oil products as a single product, then Brent and WTI can be considered as complements. For metal complements, a change in demand for the product will affect all metals similarly, causing a positive relationship between their prices, assuming that the production remains unchanged. For substitutes, a negative relationship can be expected (Lattin and McAlister, 1985). Nonetheless, a clear designation of signs with respect to the price relationships between the metals in terms of joint-consumption is not possible as this depends on the aggregation level of the consumption. Overall, although the idea of commodity prices being affected by joint consumption is comprehensible, there is limited literature investigating this effect in detail, as compared to the investigations on the joint production effects. The key question remains as to which extent joint consumption affect the related metal prices.

Therefore, the main objective of this paper is to analyze the causal relationship between metal prices with respect to their nature of joint production and consumption. In doing so, we propose two hypotheses that are the focus of our test set-ups. We use long-range real monthly price data and the approach for testing Granger-causality proposed by Toda and Yamamoto (1995), which is an extension of the conventional Granger-causality test (Granger, 1969). Our main contribution to the existing literature is the impact of joint consumption on the causal relationship between metal prices, which has not been analyzed before to the best knowledge of the authors. We believe that our results, which are based on well elaborated statistical framework, has the potential of improving the predictability of metal prices by including the related companion metal prices in existing economic models.

\section{Literature review}

There are three literature streams that we looked into in detail within the framework of our analysis. To begin with, there are numerous papers that have analyzed the general causality relationship between metal prices. As an example, Chan and Mountain (1988), Ciner (2001) as well as(Krawiec and Górska Anna, 2015) investigated the Granger-causality between prices of gold and silver and reported that gold price Granger-causes the price of silver. In addition, (Krawiec and Górska Anna, 2015) also investigated the price relationships between gold, silver and other precious metals such as platinum and palladium. Test results indicate causal links between silver and platinum as well as 
between palladium and silver. Others papers apply the Toda-Yamamoto approach in order to test for causality between metal prices. For example, Śmiech and Papież (2012) analyzed causality between gold, silver, platinum and copper using monthly prices between 2000 and 2012. Interestingly, their results show that copper Granger-causes the prices of the remaining metals for the period between 2000 and 2003. However, from 2004 onwards, the prices of gold, silver and copper were Grangercaused by platinum. Aiming at contributing to the risk mitigation strategies for the parties trading at the London Metal Exchange (LME), Basoglu et al. (2014) analyzed the causality between all nonferrous metals traded at the LME using daily price series for the period of 2000 and 2013. The authors conduct the test for several optimal lag lengths for the bivariate VAR models according to different information criteria. Some of the more notable results are the existence of causality flowing from aluminium to copper, lead to nickel as well as from copper to lead and to nickel. We noticed that most of the general causality analysis between metal prices involves either precious metals or industrial metals, which does not allow for an elementary scientific statement regarding the joint production or consumption of metals. The focus on these particular metals is owed to the fact that they serve as general indicators of global wealth and economic growth. For instance, gold prices are often used as a benchmark in forecasting inflation (Ghosh et al., 2004; Neill Fortune, 1987) whereas industrial metal demand such as steel and copper serve as an indication for growth in the national or global GDP (Binder et al., 2006; Ghosh, 2006; Krausmann et al., 2009). However, the fact that several industrial metals react towards the same macroeconomic factors indicates that there might be a systematic relationship between metals that are applied in the same consumption field.

This leads us to the next stream of literature, namely the price relationship between metals that are jointly consumed. However, there is a limited amount of literature in this field of research. One of the few studies that mention this joint consumption effect is Fizaine (2013), in which the author argues that the evolution of market prices of two metals is determined by the balance ratio of their respective demands. He further mentions that the possibility of a cointegration between metals that share a same field of consumption cannot be neglected; suggesting further research is required in order to analyze this effect in detail. In investigating the co-movements of metal prices, Pradhananga (2016) argues that the price of metals that share common application field may move together and that a demand shock in a particular metal can be transmitted to the companion metal. Similarly, Jerrett and Cuddington (2008), who observed price trends and cycles in prices of steel, pig iron and molybdenum, suggests that there are significantly higher chances of similar trends in metal prices if the prices are driven by demand as opposed to supply shocks. This relationship was again reiterated by Rossen (2015) in her research of co-movements and long-run trends of metal prices using price series dating from 1910. Although these studies did mention the possible effects of joint consumption on metal prices, empirical evidence to support this is not available to the best knowledge of the authors. Hence, we hope to contribute to closing this research gap by our analysis of Granger-causality among metals prices that are jointlyconsumed. 
The last stream of literature that we reviewed is the price dependency of jointly-produced metals. The tendency for commodity prices to move according to a similar trend may be the effects of markets reacting in a similar way to the same information (Buti and Sapir, 1998). Metals that are jointly produced are a good example for this, where the production of companion metals in a mine depend greatly on the market situation of the primary metal, which in turn, depend on a variety of macro and microeconomic factors. However, due to the insignificant role of by-product metals in the past global economies and lack of data, research on price dependency between primary and their respective companion metals are limited (Fizaine, 2013). One of the earliest research in this field was conducted by Campbell (1985). He used the non-parametric sign test in order to analyze the price movements and fluctuations of co-products in the US metal mining industry. The findings show that prices of lead and zinc, as well as gold and silver, moved together strongly. Interestingly, both of these pairs of metals have the strongest co-product relationship among all metals that he analyzed. Kim and Heo (2012) conducted Granger-causality analysis for prices from 2004 to 2011 of by-product metals that are present in a thin-film photovoltaic module, such as germanium, indium, cadmium and selenium, and their respective primary metals, zinc and copper. Based on the results, they found evidence of unidirectional causality flowing from zinc to cadmium and germanium, as well as from copper to selenium. Afflerbach et al. (2014) tested the price correlations of primary metals and by-products using a profit-maximizing optimization model and a subsequent simple regression analysis that represents the extraction strategy of mining companies. Out of 13 metal pairs, only germanium and zinc, as well as tin and copper, show significant relationship whereas aluminium and gallium, as well as cobalt and nickel, show weak dependency with each other. All in all, it can be seen that a relationship between jointly-produced metal prices does exist. However, previous studies were conducted using limited sets of metals and were often carried out using either qualitative, analytical or even simple statistical approaches such as correlation or sign test (Jordan, 2018). A consistent causality analysis using the improved Toda Yamamoto approach between wide spectrums of jointlyproduced metals is still unavailable, to which we are able to contribute via this paper.

\section{Theoretical basis of metal relationships}

In this chapter, the concepts and existing theories on the joint production and joint consumption of metals are briefly explained, which are then used as the foundation in defining the research hypotheses.

\subsection{Joint production of metals}

Most of the by-products are extracted from the ores of the primary metals, where they are usually found in low concentration. This means that the production of the by-products is driven by the demand and output of primary metals and not by their own demand, even if the price of the by-product 
increases greatly. This is known as the capacity constraint and is shown exemplarily in Figure 3-1 (left), where the supply of a by-product becomes inelastic to its own price as the production increases. The capacity constraint depends on the production of the primary metal, which in turn depends on its price. Similarly, the co-product supply is also limited by the capacity constraint of the primary metal. However, the significantly higher prices and large production volume of a co-product can alter the mining strategy, as illustrated in Figure 3-1 (right). Once the price of co-products increases due to higher demand, mine operators will increase the production of the mine. This means that the capacity constraint of a co-product is not limited to the current production of the primary metal, instead the maximum capacity of a mine. Furthermore, the joint production costs are shared between the primary metal and the co-products. This means that the supply function of a co-product contains its own price as well as the joint costs necessary for the production of both primary metal and the co-product (Tilton and Guzmán, 2016).
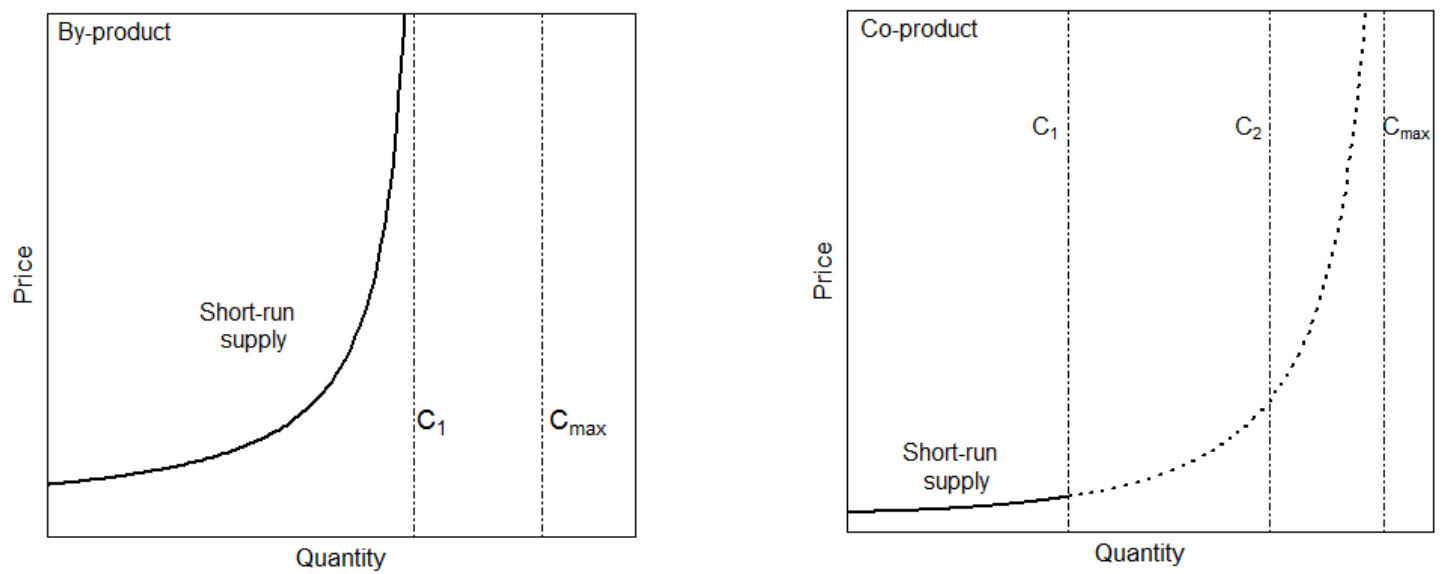

Figure 3-1: Supply curve of a by-product (left) and the supply curve of a co-product (right). The short-run supply of a byproduct is constrained by the current production of a primary metal $\left(\mathrm{C}_{1}\right)$. Even if the price of a by-product increases, the production of a mine remains unchanged and will not be increased even if the mine is not operating at capacity $\left(\mathrm{C}_{\max }\right)$. The supply of the co-product is also initially constrained by the production of the primary metal $\left(\mathrm{C}_{1}\right)$. However, once the price of the co-product increases, the production of the primary metal is increased by mine operators, thus shifting the capacity constraint $\left(\mathrm{C}_{2}\right)$. This is done in multiple stages until the maximum operating capacity of the mine $\left(\mathrm{C}_{\max }\right)$ is reached.

In defining our hypothesis, we assume that prices of metals that are jointly produced will have a negative relationship in terms of their prices. For instance, a price increase of a primary metal will cause mine operators to increase production. This leads to a corresponding increase in the production of the co- and by-products. Suppose that their demand remains unchanged, this will consequently cause an overproduction of co- and by-products, thus depreciating the price. Therefore, we assume that the price of a primary metal Granger-causes the price of its co- and by-product metals. Since the coproduct affects the mining strategy and shares operational costs with primary metals and other coproducts, their prices are assumed to hold the ability to Granger-cause the price of a primary metal as well. Lastly, we assume that the by-products will not Granger-cause the price of neither primary metal nor the co-products. Although it is possible for the market of a by-product metal to change drastically, 
forcing by-products to be treated as co-products or even primary metals, this has not happened in the past and remains very unlikely in the future as well (Fizaine 2013).

$\mathbf{1}^{\text {st }}$ hypothesis: The price of primary metals Granger-causes the price of co- and by-products, and price of co-products Granger-causes the price of primary metals and other co-products.

Apart from non-ferrous industrial metals, we also considered the primary production of precious metals and platinum group elements. The primary metals and their corresponding co- and by-products that we consider in our analysis are listed in Table 3-1. The metal pairs are selected via a two-stage classification process. Firstly, we conducted a literature research in Google Scholar in order to identify metals that are classified as co- and by-products relative to their respective primary metals. Studies that provide this classification in the literature are listed in Table 3-1. However, the classifications in the existing literature might not be complete since most of the studies only focus on certain sets of metals for their analysis. For instance, Campbell (1985) only classified selected metals that are relevant to the US economy. Therefore, in the second stage, we complement the list of metal pairs using the wheel of metal companionability by (Nassar et al., 2015). The selection of metals is limited at a cutoff level of $40 \%$, as we assumed that any production level below that can be considered too low to be affected by the primary metal and that the companion metals will most likely end-up in residues. In order to be consistent with our complementation of the metal pairs, metals that were included according to the wheel of metal companionability are classified as by-products of their respective primary metals. In order to test the robustness of our results, the cutoff point is altered in a sensitivity analysis to determine its implications of the results.

Table 3-1: List of primary metals and their corresponding co-product and by-product metals based on selected literature and own assumptions.

\begin{tabular}{|l|l|l|l|}
\hline Primary metal & Co-Product & By-Product & Source \\
\hline $\mathrm{Al}$ & \multicolumn{1}{|c}{-} & $\mathrm{Ga}$ & (Nassar et al., 2015) \\
\hline $\mathrm{Ag}$ & $\mathrm{Au}, \mathrm{Pb}$ & $\mathrm{Zn}$ & (Ayres et al., 2003; Campbell, 1985) \\
\hline $\mathrm{Au}$ & $\mathrm{Ag}$ & $\mathrm{Cu}, \mathrm{Zn}, \mathrm{Pb}$ & (Campbell, 1985) \\
\hline $\mathrm{Cu}$ & $\mathrm{Mo}, \mathrm{Ag}, \mathrm{Au}$ & $\mathrm{Se}, \mathrm{Co}, \mathrm{Zn}, \mathrm{Pb}$ & $\begin{array}{l}\text { (Ayres et al., 2003; Campbell, 1985; } \\
\text { Hustrulid and Bullock, 2001; Rankin, 2011) }\end{array}$ \\
\hline $\mathrm{Ni}$ & - & $\mathrm{Cu}, \mathrm{Pd}, \mathrm{Co}$ & $\begin{array}{l}\text { (Krawiec and Górska Anna, 2015; Nassar et } \\
\text { al., 2015; Rankin, 2011) }\end{array}$ \\
\hline $\mathrm{Pb}$ & $\mathrm{Zn}, \mathrm{Au}, \mathrm{Ag}$ & $\mathrm{Sb}, \mathrm{Ag}, \mathrm{Bi}, \mathrm{Se} \mathrm{Cu}$ & $\begin{array}{l}\text { (Campbell, 1985; Hustrulid and Bullock, } \\
\text { 2001; Nassar et al., 2015; Rankin, 2011) }\end{array}$ \\
\hline $\mathrm{Pt}$ & - & $\mathrm{Pd}, \mathrm{Rh}$ & $\begin{array}{l}\text { (Hustrulid and Bullock, 2001; Nassar et al., } \\
\text { 2015; Rankin, 2011) }\end{array}$ \\
\hline $\mathrm{Zn}$ & & $\mathrm{Cd}, \mathrm{In}, \mathrm{Ge}, \mathrm{Ga} \mathrm{Cu}$ & $\begin{array}{l}\text { (Campbell, 1985; Hustrulid and Bullock, } \\
\text { 2001; Nassar et al., 2015; Rankin, 2011) }\end{array}$ \\
\hline
\end{tabular}




\subsection{Joint consumption of metals}

Joint-consumption has a much broader scope as it can be represented at various aggregation levels. For instance, it can be understood as the simultaneous use of metals either in a single product, such as nickel and cadmium in Ni-Cd batteries or in an entire field of application, such as nickel (from Ni-Cd batteries) and lead (from $\mathrm{Pb}$-acid batteries) in electrical storage systems. In order to have a consistent methodology in selecting the metal pairs, we identify the jointly-consumed metals according to their end-use products as precise as possible. A literature research is conducted to identify the major enduses of selected metals. Any end-use with a market share of less than $30 \%$ is not considered further in the analysis since we assume that the relatively small market share is not significant to cause a causality relationship between the metals. Nonetheless, a sensitivity analysis is conducted by reducing the cutoff point to investigate the effects of this limit on the causal relationship between metal prices.

The application of 13 different metals and their corresponding companion metals are identified, as listed in Table 3-2. The metals are limited to metallic elements and metalloids that are significant to the functionality of that particular application and are not easily substituted by other metals. For example, almost $80 \%$ of global lead demand is used in making lead-acid batteries (Risopatron, 2014). While hydrogen and sulphur are required as electrolytes to operate the batteries, neither metallic elements nor metalloids are required in addition to lead to ensure the functionality of a lead-acid battery. Therefore, lead is not selected as a primary metal to be investigated in this section as it does not have any companion metal that fits our requirements.

Besides that, to limit the number of metals and the application fields in our analysis, only fields with more than $30 \%$ of global consumption market share is considered. As an example, the high electrical conductivity of silver makes it one of the primary elements conductive paste in crystalline solar cells (Saga, 2010). Despite the massive growth of the photovoltaics (PV) market in recent years, only less than $8 \%$ of the global silver demand is used in PV modules fabrication. Furthermore, due to the high price of silver, substitution of silver with copper as the conductive paste is being intensively researched and is at the beginning stages of a market entry (ITRPV, 2018). Therefore, the elements of a PV module are not selected to be analyzed as joint consumers of silver in this section. Instead, copper and gold are chosen as joint consumers of silver, as significant amount of silver is used for capacitors and electric switches (electronic components) and for making jewelry and coins.

In order to propose a hypothesis on the Granger-causality of the prices of these elements, we assume that jointly-consumed metals will Granger-cause each other's prices. Since the selection requirement for the metal pairs is that they cannot be easily substituted in their respective products, the metals pairs tested for joint consumption should hypothetically have complementing relationships, i.e. price movements in the same direction. For instance, a significant amount of nickel and chromium are used as alloying elements to produce stainless steel. Therefore, in case of an increase in steel demand, the 
demand of both nickel and chromium will increase. Assuming that production remains constant, prices of both metals will increase simultaneously, an effect that can be captured by the Granger-causality test. Hence our second hypothesis is defined as follows:

$\mathbf{2}^{\text {nd }}$ hypothesis: Metals that are jointly consumed will have at least a unidirectional Granger-causality between their prices, given that the market share of the application field is large enough.

Table 3-2: List of metals and their respective companion metals that are present in the main end-uses

\begin{tabular}{|c|c|c|c|}
\hline Metal & $\begin{array}{l}\text { Companion } \\
\text { metal }\end{array}$ & Main end-uses of metals and their respective market shares & Source \\
\hline $\mathrm{Ag}$ & $\mathrm{Cu}, \mathrm{Au}$ & $\begin{array}{l}35 \% \text { of global silver demand is used in making jewelry and } \\
\text { coins, together with gold. } 30 \% \text { of global silver demand is used } \\
\text { in electronics, such as in capacitors or electrical switches, where } \\
\text { copper is also heavily involved. }\end{array}$ & $\begin{array}{l}\text { (Thomson Reuters } \\
\text { and The Silver } \\
\text { Institute, 2018) }\end{array}$ \\
\hline $\mathrm{Au}$ & $\mathrm{Ag}$ & $\begin{array}{l}\text { Jewelry represents the largest source of global demand with a } \\
\text { market share of } 50 \% \text {. }\end{array}$ & $\begin{array}{l}\text { (World Gold } \\
\text { Council, 2018) }\end{array}$ \\
\hline $\mathrm{Cd}$ & $\mathrm{Ni}$ & $\begin{array}{l}\text { Manufacturing of nickel-cadmium }(\mathrm{Ni}-\mathrm{Cd}) \text { batteries requires } \\
75 \% \text { of the global cadmium demand. }\end{array}$ & (Plachy, 2000) \\
\hline $\mathrm{Co}$ & $\mathrm{Li}, \mathrm{Ni}, \mathrm{Cr}$ & $\begin{array}{l}\text { With more than } 40 \% \text { of market share, the main application of } \\
\text { cobalt is in lithium-ion batteries with lithium and nickel. The } \\
\text { remaining demand is used in making superalloys and hard } \\
\text { materials, in which nickel and chromium are also used. }\end{array}$ & $\begin{array}{l}\text { (Donachie and } \\
\text { Donachie, 2008; } \\
\text { GEMC, 2018; } \\
\text { Palisade Research, } \\
\text { 2016) }\end{array}$ \\
\hline $\mathrm{Cr}$ & $\mathrm{Fe}$ & $\begin{array}{l}\text { The main field of application of chromium is Ferrochrome with } \\
95 \% \text { of global demand. }\end{array}$ & (Lunk, 2015) \\
\hline $\mathrm{Cu}$ & $\mathrm{Al}, \mathrm{Fe}, \mathrm{Zn}$ & $\begin{array}{l}\text { Copper is mainly used for electrical wiring. In terms of the } \\
\text { transmission grid, copper is used with steel (steel core copper) } \\
\text { for earthing of electrical installations and telephone cables. } \\
\text { Copper is also used in making transformers and electrical motors } \\
\text { with steel and aluminium. Besides that, copper is also used with } \\
\text { zinc for brassware. }\end{array}$ & $\begin{array}{l}\text { (IWCC and ICA, } \\
\text { 2017; Nordelöf et } \\
\text { al., 2018) }\end{array}$ \\
\hline $\mathrm{Ga}$ & $\mathrm{As}, \mathrm{Sb}, \mathrm{In}$ & $\begin{array}{l}\text { Almost } 90 \% \text { of gallium demand is in semiconductor or semi- } \\
\text { insulating applications, of which } 50 \% \text { is used in integrated } \\
\text { circuits and transistors, } 38 \% \text { in LEDs for general lighting. Only } \\
\text { about } 9 \% \text { of global gallium demand is used in photovoltaics. } \\
\text { Gallium-based semiconductors are often used together with } \\
\text { various elements, among which we choose antimony, arsenic and } \\
\text { indium to be analyzed. }\end{array}$ & $\begin{array}{l}\text { (Hecht, 2001; } \\
\text { Roskill, 2014) }\end{array}$ \\
\hline In & Sn & $\begin{array}{l}64 \% \text { of global indium demand goes into manufacturing } \\
\text { transparent conducting oxides (TCO) for flat panel displays and } \\
\text { photovoltaics. Indium-tin-oxide is the most common TCO due to } \\
\text { it's outstanding structural, electrical and optical properties. }\end{array}$ & $\begin{array}{l}\text { (Kim et al., 1999; } \\
\text { Lokanc et al., 2015) }\end{array}$ \\
\hline Mo & $\mathrm{Ni}, \mathrm{Fe}, \mathrm{Cr}$ & $\begin{array}{l}\text { The high temperature, wear and corrosion resistance properties } \\
\text { of molybdenum make it very suitable for applications such as } \\
\text { industrial furnaces. Almost the entire molybdenum produced is } \\
\text { used as an alloying element in steel, together with chromium and } \\
\text { nickel. }\end{array}$ & $\begin{array}{l}\text { (Imgrund and } \\
\text { Kinsman, 2007; } \\
\text { Shields, 2013) }\end{array}$ \\
\hline $\mathrm{Ni}$ & $\begin{array}{l}\mathrm{Fe}, \mathrm{Cr}, \mathrm{Cu}, \\
\mathrm{Mo}\end{array}$ & $\begin{array}{l}\text { Around } 80 \% \text { of global nickel demand is deployed to produce } \\
\text { stainless steel or nickel-based alloys. Other than steel and } \\
\text { chromium which are widely present in stainless steel, copper and } \\
\text { molybdenum are also used in certain types of stainless steel to } \\
\text { enhance corrosion resistance. }\end{array}$ & $\begin{array}{l}\text { (Glencore, 2017; } \\
\text { Tsujikawa et al., } \\
\text { 2008) }\end{array}$ \\
\hline
\end{tabular}




\begin{tabular}{|l|l|l|l|}
\hline Pt & $\begin{array}{l}\mathrm{Rh}, \mathrm{Pd}, \mathrm{Au}, \\
\mathrm{Ag}\end{array}$ & $\begin{array}{l}\text { Together with rhodium and palladium, 40 \% of all platinum } \\
\text { produced are used in making catalytic converters. Another 30\% } \\
\text { is applied to making jewelry. }\end{array}$ & (Oxford, 2018) \\
\hline $\mathrm{Sn}$ & $\mathrm{Pb}, \mathrm{Cu}$ & $\begin{array}{l}\text { Soldering paste is the top application of tin, amounting to almost } \\
50 \% \text { of the global demand. Generally, solder pastes are made of } \\
\text { a tin-lead alloy. However, tin-copper solder pastes have been } \\
\text { gaining market shares in the industry as a low-cost substitute and } \\
\text { as a lead-free alternative. }\end{array}$ & $\begin{array}{l}\text { (Consolidated Tin } \\
\text { Mines Ltd., 2018; } \\
\text { Geibig J.R. and } \\
\text { Socolof M.L., } \\
\text { 2005; John Sykes, } \\
\text { 2012) }\end{array}$ \\
\hline $\mathrm{Zn}$ & $\mathrm{Fe}, \mathrm{Cu}$ & $\begin{array}{l}50 \% \text { of global zinc demand is used for galvanizing steel whereas } \\
\text { (Mohr et al., 2018; }\end{array}$ & $\begin{array}{l}\text { Risopatron, 2014; } \\
\text { USGS, 2018) }\end{array}$ \\
\hline
\end{tabular}

\section{Dataset and descriptive statistics}

The nominal monthly metal prices are obtained from the German Federal Institute for Geosciences and Natural Resources (BGR). We transform the nominal prices to real prices by dividing them with the seasonally adjusted consumer price index (CPI), which is obtained from the Federal Reserve Bank of

St. Louis. One of our main contributions to existing literature is the use of long-range monthly data in testing causality, with an average of 468 samples across all metals. Silver, copper, lead and tin have the largest sample size with price series dating back to 1960, whereas gallium has the smallest sample size, with a price series starting from 2003. However, this limited time series means that any results that we obtain are only based on these time period and possible relationship beyond this period cannot be captured by our analysis. Since we conduct a pair-wise causality test, the number of sample in each metal pair will be adjusted accordingly to prevent any data gap in the metal pairs. The descriptive statistics of the data are listed in Table 4-1, including mean, maximum and minimum price, mean, median, standard deviation, standard error, skewness, and kurtosis. All values shown in Table 4-1 are obtained for the price levels, as the Toda-Yamamoto approach calls for the use of price levels without any data transformation.

Table 4-1: Descriptive statistics of monthly prices for all of the analyzed metals according to their respective available sample period. The monetary unit $\$$ refers to US dollars. Min and Max refer to the minimum and maximum price respectively in the entire time series whereas Std. Dev. and Std. Error refers to the standard deviation and standard error, respectively.

\begin{tabular}{cccccccccccc}
\hline Metal & Sample period & Unit & $\begin{array}{c}\text { Data } \\
\text { Points }\end{array}$ & Min & Max & Mean & Median & Std. Dev. & $\begin{array}{c}\text { Std. } \\
\text { Error }\end{array}$ & Skewness & Kurtosis \\
\hline $\mathrm{Ag}$ & $01.1960-12.2013$ & $\$ / \mathrm{oz}$ & 648 & 5.1 & 109.8 & 13.4 & 10.0 & 9.9 & 0.4 & 3.76 & 24.47 \\
\hline $\mathrm{Al}$ & $01.1972-12.2013$ & $\$ / \mathrm{t}$ & 504 & 1363.2 & 6622.6 & 2620.7 & 2341.0 & 899.9 & 40.1 & 1.25 & 1.43 \\
\hline $\mathrm{As}$ & $07.1992-12.2013$ & $\$ / \mathrm{lb}$ & 258 & 1.0 & 3.9 & 1.6 & 1.4 & 0.4 & 0.0 & 1.87 & 4.12 \\
\hline $\mathrm{Au}$ & $01.1971-12.2013$ & $\$ / \mathrm{oz}$ & 516 & 262.6 & 1885.9 & 732.8 & 654.4 & 336.8 & 14.8 & 1.18 & 1.01 \\
\hline $\mathrm{Bi}$ & $01.1973-12.2013$ & $\$ / \mathrm{t}$ & 492 & 6592.4 & 73746.1 & 18231.9 & 12809.2 & 12751.7 & 574.9 & 1.79 & 2.83 \\
\hline $\mathrm{Cd}$ & $01.1979-12.2013$ & $\$ / \mathrm{kg}$ & 420 & 0.5 & 34.4 & 5.7 & 3.6 & 6.6 & 0.3 & 2.34 & 5.62 \\
\hline $\mathrm{Co}$ & $01.1976-12.2013$ & $\$ / \mathrm{t}$ & 456 & 16932.0 & 283190.1 & 55705.1 & 45105.0 & 38570.9 & 1806.2 & 3.04 & 13.06 \\
\hline $\mathrm{Cr}$ & $01.1974-12.2013$ & $\$ / \mathrm{t}$ & 480 & 782.7 & 6401.0 & 2254.3 & 2154.1 & 960.2 & 43.8 & 1.02 & 1.54 \\
\hline $\mathrm{Cu}$ & $01.1960-12.2013$ & $\$ / \mathrm{t}$ & 648 & 1583.3 & 13743.9 & 4006.0 & 3493.2 & 2000.2 & 78.6 & 1.27 & 1.76 \\
\hline $\mathrm{Fe}$ & $01.1981-12.2013$ & $\$ / \mathrm{t}$ & 396 & 241.9 & 1244.5 & 460.8 & 419.9 & 147.3 & 7.4 & 1.66 & 5.47 \\
\hline $\mathrm{Ga}$ & $01.2002-12.2013$ & $\$ / \mathrm{kg}$ & 144 & 219.4 & 909.9 & 432.6 & 366.1 & 156.3 & 13.0 & 1.19 & 0.70 \\
\hline $\mathrm{Ge}$ & $01.1995-12.2013$ & $\$ / \mathrm{kg}$ & 228 & 355703.1 & 1973611.1 & 887106.5 & 867828.8 & 363720.4 & 24088.0 & 0.57 & 0.11 \\
\hline $\mathrm{In}$ & $01.1973-12.2013$ & $\$ / \mathrm{t}$ & 492 & 102114.4 & 1793064.9 & 527487.8 & 438659.9 & 344060.7 & 15511.5 & 1.16 & 1.15 \\
\hline $\mathrm{Li}$ & $01.1977-12.2013$ & $\$ / \mathrm{t}$ & 444 & 2530.2 & 6782.3 & 3633.9 & 3023.5 & 1273.9 & 60.5 & 1.44 & 0.46 \\
\hline $\mathrm{Mo}$ & $01.1974-12.2013$ & $\$ / \mathrm{kg}$ & 480 & 7947.3 & 221020.8 & 38420.9 & 21577.4 & 35027.6 & 1598.8 & 1.65 & 3.16 \\
\hline & & & & & & & & & & 10
\end{tabular}




\begin{tabular}{ccccccccccccc}
\hline $\mathrm{Ni}$ & $01.1971-12.2013$ & $\$ / \mathrm{t}$ & 516 & 5144.2 & 55010.4 & 14803.3 & 14392.9 & 6867.5 & 302.3 & 1.95 & 6.30 \\
\hline $\mathrm{Pb}$ & $01.1960-12.2013$ & $\$ / \mathrm{t}$ & 648 & 361.4 & 4170.2 & 1195.8 & 903.6 & 744.8 & 29.3 & 1.38 & 1.46 \\
\hline $\mathrm{Pd}$ & $01.1971-12.2013$ & $\$ / \mathrm{oz}$ & 516 & 125.5 & 1293.4 & 331.9 & 257.7 & 188.7 & 8.3 & 1.64 & 3.03 \\
\hline $\mathrm{Pt}$ & $01.1973-12.2013$ & $\$ / \mathrm{oz}$ & 492 & 455.4 & 2437.4 & 937.4 & 855.0 & 373.2 & 16.8 & 1.08 & 0.80 \\
\hline $\mathrm{Rh}$ & $01.2000-12.2013$ & $\$ / \mathrm{oz}$ & 168 & 570.1 & 9789.6 & 2544.3 & 1748.5 & 2150.2 & 165.9 & 1.66 & 2.03 \\
\hline $\mathrm{Sb}$ & $01.1969-12.2013$ & $\$ / \mathrm{t}$ & 540 & 1254.9 & 16131.2 & 5895.3 & 4974.0 & 3418.1 & 147.1 & 0.93 & 0.27 \\
\hline $\mathrm{Se}$ & $01.1979-12.2013$ & $\$ / \mathrm{kg}$ & 420 & 5.4 & 145.9 & 38.9 & 22.3 & 34.1 & 1.7 & 1.27 & 0.77 \\
\hline $\mathrm{Sn}$ & $01.1960-12.2013$ & $\$ / \mathrm{t}$ & 648 & 4518.9 & 51954.0 & 18584.6 & 17760.8 & 10452.7 & 410.6 & 0.93 & 0.40 \\
\hline $\mathrm{Zn}$ & $01.1971-12.2013$ & $\$ / \mathrm{t}$ & 516 & 897.8 & 7975.6 & 2014.5 & 1792.2 & 978.9 & 43.1 & 3.05 & 13.19 \\
\hline
\end{tabular}

\section{Research methodology}

Probably the most influential work on causality in economics is (Granger 1969), which led to the coining of the term Granger-causality. The success of Granger-causality lies predominantly in the ability of the data-driven methodology in allowing researchers to identify directional influences of variables without any prior knowledge on the subject matters. Despite being widely used in research up to date, the Granger-causality test has a few downfalls which have been addressed in the literature. These include spurious results (Chowdhury, 1987) and the extreme sensitivity towards the form of time series (Fizaine, 2015; Roberts and Nord, 2006) and model specification (Yakubu and Abdul Jalil, 2016). In order to rectify these downfalls, Toda and Yamamoto (1995) proposed an expansion, which improves the power of Granger-causality test (Doran and Rambaldi, 1997) and have since been applied in economics particularly to analyze causalities between macroeconomic factors and commodity prices (see Jain and Ghosh, 2013; Klotz et al., 2014; Nazlioglu and Soytas, 2011).

In this paper, we apply the Toda-Yamamoto approach of Granger-causality to conduct a pair-wise causality test on metal prices. We set up a pair of price series of metals that fit the joint production or joint consumption criteria. Since the time series of two metals usually have different temporal availability, we trimmed the time series to ensure that they have the same time period without any gaps in-between. For example, in testing causality between silver and aluminium, we used silver prices starting from 1972 since the price of aluminium before that is unavailable. However, prices from 1960 are used to test for causality between silver and copper, as data for both metals are available for the entire period. This implies that different time periods of a single metal is used to test against different metal. The actual sample period for each metal pairs is listed in Table A.1 (appendix).

In the next step, each time series is tested for unit roots in order to determine their order of integration (I) and the corresponding maximum order of integration $(m)$ of the pair of metals. For this, we apply the Augmented Dickey-Fuller (ADF) (see Dickey and Fuller, 1979) and Kwiatkowski-PhillipsSchmidt-Shin (KPSS) (see Kwiatkowski et al., 1992) tests. The ADF-test tests the null hypothesis that a unit root is present whereas the KPSS test is used to test the null hypothesis that a time series is stationary against the alternative of a unit root. The higher order of the integration between the pair of time series is selected as the maximum order of integration for the corresponding metal pair. For 
example, if two time series $X$ and $Y$ have an order of integration of $\mathrm{I}(1)$ and $\mathrm{I}(2)$ respectively, then $m$ is selected to be 2 for the pair $X$ and $Y$.

Since we are only conducting a pair-wise causality test, there is a possibility that our approach still suffers from the bias due to possible omitted variables (see Sims, 1980; Lütkepohl, 1982). Therefore, we complement the Toda-Yamamoto approach by testing for cointegration ranks. Although testing for cointegration does not determine the direction of causality, it does reduce the probability that the results are spurious due to omitted variables (Stern, 2011) and has become a prerequisite to the TodaYamamoto approach of causality testing (e.g. see Wolde-Rufael, 2006; Alimi and Ofonyelu, 2013; Chaido Dritsaki, 2017). According to Engle and Granger (1987), if a co-integration is present, there should be causality at least in one direction. When both time series of a metal pair have the same order of integration, we conduct a trace cointegration test as proposed by Johansen (1991), in which we estimate a vector error correction model (VECM). This test does not affect the results of the causality at this point. It is used at the end of the Granger-causality test to cross-check the results.

For each pair of time series, a vector autoregressive (VAR) model, as presented in equation 1 and 2, is then set up. The levels of the price series are used to fit the model as opposed to the transformed time series, as for how it is usually done in a conventional causality test.

$$
\begin{aligned}
X_{t} & =\sum_{i=1}^{p+m} \alpha_{i} X_{t-i}+\sum_{j=1}^{p+m} \beta_{j} Y_{t-j}+\varepsilon_{x t} \\
Y_{t} & =\sum_{i=1}^{p+m} \theta_{i} Y_{t-i}+\sum_{j=1}^{p+m} \delta_{j} X_{t-j}+\varepsilon_{y t}
\end{aligned}
$$

Where $p$ is the number of optimal lags, $m$ is the maximum order of integration and $\varepsilon_{x}$ and $\varepsilon_{y}$ are the residuals assumed to have zero mean, constant variance and no autocorrelation. If the variance of $\varepsilon_{x}$ and $\varepsilon_{y}$ can be reduced by including the lagged terms of $Y$ (or $\left.X\right)$ in the first equation (or second), then it can be implied that $Y$ (or $X$ ) Granger-causes $X$ (or $Y$ ). In the equations above, causality exists if the coefficients $\beta_{j}$ or $\delta_{j}$ are significantly different from zero, which can be tested by performing a Waldtest under the null hypothesis that the coefficients $\beta_{j}$ or $\delta_{j}$ are zero, assuming a covariance stationarity of $X$ and $Y$.

Another difference between the Toda-Yamamoto and the traditional Granger-causality test is that the former approach sets up and estimates a $\operatorname{VAR}(p+m)$ while the latter estimates a $\operatorname{VAR}(p)$ model. The optimal lag length $(p)$ of the VAR model is chosen using the Bayesian Information Criteria (BIC) (Schwarz, 1978). We ensure that the VAR model is well specified before estimating it by testing for serial autocorrelation in the residuals using the Lagrange Multiplier (LM) test based on (Breusch, 1978) 
and (Godfrey, 1978), also known as the BG-test. Since we are using monthly data, we choose the lag length for the BG-test to be 12. If the VAR-model shows any signs of serial autocorrelation, we increase the lag length and repeat the test again until all autocorrelation issues are solved. The lag length, at which no serial autocorrelation among residuals are observed, is selected to be the final optimal lag length, $p$.

The next step is to test for Granger-causality. We use the Wald-test to analyze whether lagged information of a variable provides any statistically significant information about another variable in the presence of lagged variable. For this, we define the null, $\mathrm{H}_{0}$, and alternative, $\mathrm{H}_{1}$, hypotheses as shown in equation 3 to 6 . We do not include the additional lags, $m$, in the Wald-test. This is known as the modified Wald-test as proposed by Toda and Yamamoto. This ensures the Wald statistics to still be asymptotically $\chi^{2}$ distributed with $p$ degrees of freedom regardless of the order of integration and the cointegration nature of the time series (Giles, 1997; Hacker and Hatemi-J, 2006; Mishra, 2014). The causality results are then cross-checked by comparing them to the co-integration results based on the Johansen test.

$$
\begin{aligned}
& \mathrm{H}_{0}=\sum_{j=1}^{p} \beta_{j}=0 \quad \begin{array}{l}
; Y \text { does not Granger- } \\
\text { cause } X
\end{array} \\
& \text { (3) } \quad \mathrm{H}_{0}=\sum_{j=1}^{p} \delta_{j_{j}}=0 \quad \begin{array}{l}
\begin{array}{l}
\mathrm{X} \text { does not Granger- } \\
\text { cause } \mathrm{Y}
\end{array} \\
\text { ing }
\end{array} \\
& \mathrm{H}_{1}=\sum_{j=1}^{p} \beta_{j} \neq 0 \quad ; \text { Y Granger-causes X } \\
& \mathrm{H}_{1}=\sum_{j=1}^{p} \delta_{j_{j}} \neq 0 \quad ; \mathrm{X} \text { Granger-cause } \mathrm{Y}
\end{aligned}
$$

\section{Empirical results and discussion}

We present the results of the tests for unit root and for cointegration for all pairs of metals, without differentiating their nature of joint production or consumption. The differentiation is made for the results of the Granger-causality test so that we are able to present and discuss the results in detail. Table A.1 (Appendix) shows the results of the ADF and KPSS tests. Almost all of the metal price series are stationary at first order according to the ADF test at $1 \%$ significance level and insignificant KPSS statistic. Only lithium, for the period of 1977-2013, is accepted to be stationary at $10 \%$ significance level according to the KPSS test. The maximum order of integration of all pairs of time series, $m$, is therefore set to be one.

Table 6-1 shows the trace and the maximum eigenvalue statistics of the Johansen cointegration test. Results indicate that 16 out of 45 metal pairs tested have at least 1 cointegration rank at the $1 \%$ significance level. Cointegration suggests that a long-term relationship exists between the prices of both metals, despite potential deviation from equilibrium levels in the short term. The cointegration results are compared to the Granger-causality results in the next section, as we expect to observe 
causal links between those 16 metal pairs. The maximum lag length used to estimate the VAR models are listed in Table A.2 (Appendix). The optimal lag lengths are initially chosen based on BIC.

However, the residuals of some of the VAR model using those lag lengths exhibit autocorrelation, as can be seen from the results of the Breusch-Godfrey (BG) test in Table A.2 (Appendix). Since autocorrelation is undesirable and may lead to spurious results, we increased the lag length of those VAR models and conduct the BG again, until the all serial autocorrelation issues are solved.

Table 6-1: Results of Johansen cointegration test.

* represents $10 \%$ significance level, $* * 5 \%$ significance level and $* * * 1 \%$ significance level.

\begin{tabular}{|c|c|c|c|c|c|c|c|}
\hline Metal pair & Rank & Trace statistic & $\begin{array}{c}\text { Max. eigenvalue } \\
\text { statistic }\end{array}$ & Metal pair & Rank & Trace statistic & $\begin{array}{c}\text { Max. eigenvalue } \\
\text { statistic }\end{array}$ \\
\hline \multirow{2}{*}{$\mathrm{Ag}-\mathrm{Au}$} & 0 & $34.71 * * *$ & $34.64 * * *$ & \multirow{2}{*}{ Mo-Ag } & 0 & $16.57 * * *$ & $13.31 * *$ \\
\hline & 1 & 0.08 & 0.08 & & 1 & $3.26^{*}$ & $3.26^{*}$ \\
\hline \multirow{2}{*}{$\mathrm{Ag}-\mathrm{Cu}$} & 0 & $25.40 * * *$ & $23.83 * * *$ & \multirow{2}{*}{ Mo-Au } & 0 & $24.05 * * *$ & $22.76^{* * * *}$ \\
\hline & 1 & 1.57 & 1.57 & & 1 & 1.29 & 1.29 \\
\hline \multirow{2}{*}{$\mathrm{Ag}-\mathrm{Pb}$} & 0 & $46.29 * * *$ & $44.41 * * *$ & \multirow{2}{*}{$\mathrm{Mo}-\mathrm{Ni}$} & 0 & 10.34 & 8.28 \\
\hline & 1 & 1.88 & 1.88 & & 1 & 2.06 & 2.06 \\
\hline \multirow{2}{*}{$\mathrm{Al}-\mathrm{Ga}$} & 0 & $10.60 * *$ & $10.38^{*}$ & \multirow{2}{*}{$\mathrm{Mo}-\mathrm{Fe}$} & 0 & 8.72 & 6.68 \\
\hline & 1 & 0.22 & 0.22 & & 1 & 2.04 & 2.04 \\
\hline \multirow{2}{*}{$\mathrm{Al}-\mathrm{Cu}$} & 0 & $10.99 *$ & 9.49 & \multirow{2}{*}{$\mathrm{Mo}-\mathrm{Cr}$} & 0 & $10.66^{*}$ & 8.85 \\
\hline & 1 & 1.5 & 1.5 & & 1 & 1.81 & 1.81 \\
\hline \multirow{2}{*}{$\mathrm{Al}-\mathrm{Zn}$} & 0 & $22.81 * * *$ & $21.28 * * *$ & \multirow{2}{*}{$\mathrm{Ni}-\mathrm{Fe}$} & 0 & $27.63 * * *$ & $26.15^{* * *}$ \\
\hline & 1 & 1.53 & 1.53 & & 1 & 1.49 & 1.49 \\
\hline \multirow{2}{*}{$\mathrm{Cd}-\mathrm{Ni}$} & 0 & 10.42 & 8.08 & \multirow{2}{*}{$\mathrm{Ni}-\mathrm{Cr}$} & 0 & $31.67 * * *$ & $29.86^{* * *}$ \\
\hline & 1 & 2.34 & 2.34 & & 1 & 1.81 & 1.81 \\
\hline \multirow{2}{*}{$\mathrm{Co}-\mathrm{Li}$} & 0 & 7.83 & 6.36 & \multirow{2}{*}{$\mathrm{Ni}-\mathrm{Cu}$} & 0 & $32.87 * * *$ & $31.71 * * *$ \\
\hline & 1 & 1.47 & 1.47 & & 1 & 1.15 & 1.15 \\
\hline \multirow{2}{*}{$\mathrm{Co}-\mathrm{Ni}$} & 0 & $12.85^{* * *}$ & $10.70^{*}$ & \multirow{2}{*}{ Ni-Pd } & 0 & $11.99 *$ & $10.78 *$ \\
\hline & 1 & 2.15 & 2.15 & & 1 & 1.2 & 1.2 \\
\hline \multirow{2}{*}{$\mathrm{Co}-\mathrm{Cr}$} & 0 & $12.95^{* * *}$ & $11.37 * *$ & \multirow{2}{*}{$\mathrm{Pb}-\mathrm{Zn}$} & 0 & $17.77 * * *$ & $16.64 * * *$ \\
\hline & 1 & 1.58 & 1.58 & & 1 & 1.13 & 1.13 \\
\hline \multirow{2}{*}{$\mathrm{Cr}-\mathrm{Fe}$} & 0 & $14.68 * *$ & $13.53^{* * *}$ & \multirow{2}{*}{$\mathrm{Pb}-\mathrm{Au}$} & 0 & $27.23 * * *$ & $26.79 * * *$ \\
\hline & 1 & 1.15 & 1.15 & & 1 & 0.44 & 0.44 \\
\hline \multirow{2}{*}{$\mathrm{Cu}-\mathrm{Fe}$} & 0 & $19.18 * * *$ & $18.62 * * *$ & $\mathrm{Ph}_{-} \mathrm{Sh}$ & 0 & $21.30 * * *$ & $20.70 * * *$ \\
\hline & 1 & 0.56 & 0.56 & $\mathrm{~Pb}-\mathrm{Sb}$ & 1 & 0.6 & 0.6 \\
\hline$C_{1} 7 \mathrm{n}$ & 0 & 8.34 & 8.14 & $\mathrm{Pt} \mathrm{Ph}$ & 0 & 4.63 & 4.5 \\
\hline $\mathrm{Cu}-\mathrm{Zn}$ & 1 & 0.2 & 0.2 & Pt-Kh & 1 & 0.13 & 0.13 \\
\hline $\mathrm{Cu}_{\mathrm{u}}$ & 0 & $26.38 * * *$ & $26.34 * * *$ & Pt-Pd & 0 & 7.05 & 6.28 \\
\hline $\mathrm{Cu}-\mathrm{Au}$ & 1 & 0.04 & 0.04 & $\mathrm{Pt}-\mathrm{Pa}$ & 1 & 0.77 & 0.77 \\
\hline $\mathrm{Cu}-\mathrm{Mo}$ & 0 & $11.90 *$ & 9.35 & Pt-Ao & 0 & $15.93 * *$ & $15.46^{* * * *}$ \\
\hline Cu-Mo & 1 & 2.55 & 2.55 & Pt-Ag & 1 & 0.48 & 0.48 \\
\hline $\mathrm{Cu}-\mathrm{Se}$ & 0 & $16.08 * *$ & $14.74 * *$ & $\mathrm{Sn}-\mathrm{Pb}$ & 0 & $12.12 *$ & $11.63^{* * *}$ \\
\hline cu-se & 1 & 1.34 & 1.34 & $\mathrm{Sn}-\mathrm{Pb}$ & 1 & 0.49 & 0.49 \\
\hline $\mathrm{Cu}_{\mathrm{C}}$ & 0 & 8.95 & 8.26 & $\mathrm{Sn}_{-} \mathrm{Cu}_{3}$ & 0 & 9.15 & 8.62 \\
\hline Cu-co & 1 & 0.69 & 0.69 & $\mathrm{Sn}-\mathrm{Cu}$ & 1 & 0.53 & 0.53 \\
\hline$C_{1}-\mathrm{Ph}$ & 0 & $26.29 * * *$ & $25.07 * * *$ & $7 n_{-} \mathrm{Ag}$ & 0 & $13.86 * *$ & $12.42 * *$ \\
\hline CU-PD & 1 & 1.23 & 1.23 & Zn-Ag & 1 & 1.44 & 1.44 \\
\hline Ga-As & 0 & 8.71 & 8.61 & $7 n_{-}-A_{\mu}$ & 0 & $11.53^{*}$ & $11.29 * *$ \\
\hline Ga-As & 1 & 0.10 & 0.10 & $\mathrm{Zn}-\mathrm{Au}$ & 1 & 0.24 & 0.24 \\
\hline $\mathrm{Ga}-\mathrm{Sb}$ & 0 & 7.95 & 7.85 & Zn-In & 0 & $14.22 * *$ & $13.44 * *$ \\
\hline Ga-sb & 1 & 0.10 & 0.10 & $\mathrm{Zn}-\mathrm{In}$ & 1 & 0.77 & 0.77 \\
\hline$S_{9}=$ & 0 & 6.87 & 6.79 & $7 \mathrm{n}_{-\mathrm{Ge}}$ & 0 & 7.44 & 7.29 \\
\hline Ga-In & 1 & 0.18 & 0.18 & $\mathrm{Zn}-\mathrm{Ge}$ & 1 & 0.14 & 0.14 \\
\hline $\mathrm{In}_{-} \mathrm{Sn}$ & 0 & 7.93 & 7.42 & $7 \mathrm{n}_{-\mathrm{G}} \mathrm{g}$ & 0 & 7.42 & 7.2 \\
\hline In-Sn & 1 & 0.5 & 0.5 & Zn-Ga & 1 & 0.22 & 0.22 \\
\hline
\end{tabular}




\subsection{Joint production}

Once the VAR models are well specified, we estimate them using lag lengths of $p+m$. Table 6-2 shows the results of the Granger-causality tests between metals that are produced together. Upon cross-checking the values with the results from the cointegration tests, we identified that a causal link is present whenever a cointegration rank at $1 \%$ confidence level is present between the metals.

Our first hypothesis states that the prices of primary metals and co-products Granger-cause each other. Apart from zinc, which does not have any causality relationship with its co-products in any direction, we find strong evidence to support this hypothesis. For example, bidirectional causality is found between gold, silver and their respective co-products. This is also true for lead and its co-products, except gold where only a causality flowing from gold to lead can be identified. Bi-directional causality is also present between copper and silver as well as between copper and gold. In terms of copper and molybdenum, a unidirectional causality flows from the latter to former metal, which supports the statement by Campbell (1985), who mentioned that the production of copper ores is strongly influenced by the price of molybdenum. We also find evidence that the price of a co-product Grangercauses the price of other related co-products. For instance, molybdenum Granger-causes the prices of gold and silver, all being co-products of copper. Similarly, causal links are also present among the coproducts of lead, silver and zinc.

Our hypothesis further states that the price of primary metals and co-products Granger-causes the price of by-products. However, we obtain mixed results regarding this statement. For example, the price of gallium, which is almost primarily mined as a by-product of aluminium, is not Granger-caused by the price of aluminium. In terms of the by-products of zinc, more than $75 \%$ of global production of cadmium and indium are carried out together with zinc. Despite this significant amount, only the cadmium price is Granger-caused by the price of zinc whereas no causality is observed between zinc and indium. This result corresponds to the findings of Kim and Heo (2012), who also obtained similar directions of causal relationships between zinc, indium and cadmium. We attain expected results with regards to selenium and bismuth, whose prices are Granger-caused by the price of lead. Almost $50 \%$ of the global production of selenium and bismuth occur together with the production of lead. However, the price of nickel and platinum does not Granger-cause their respective by-products. The absence of causality between nickel and cobalt as well as between copper and cobalt is also unexpected, as nickel and copper are the main production sources of cobalt.

Overall, of the 39 metal pairs analyzed, only 22 pairs (56\%) have significant Granger-causality. While we detect a strong tendency of Granger-causality between co-products and their primary products as well as other related co-products, the same cannot be said for by-products. Therefore, we fail to conclusively prove our hypothesis that jointly-produced metals will have significant causality relationships with their primary metals. The mixed results, especially in terms of the by-products, 
support the findings of Jordan (2017), who reported that the responsiveness of the metal prices towards other metals is not strongly related to their revenue share, which is the basis for literature sources in Table 3-1 to categorize metals according to their co- and by-product nature.

Table 6-2: Test statistics of the $\chi^{2}$ Wald-test for metals that are jointly produced. $X->Y$ represents the null hypothesis of $X$ does not Granger-cause $Y$. $\beta$ represents the corresponding sum of coefficients whenever causality is present.

$*$ represents $10 \%$ significance level, ** 5\% significance level and *** $1 \%$ significance level.

\begin{tabular}{|c|c|c|c|c|c|c|c|}
\hline$X$ & $\mathrm{Y}$ & $\chi^{2}(X->Y)$ & Sum of $\beta$ & $\mathrm{X}$ & $\mathrm{Y}$ & $\chi^{2}(X->Y)$ & Sum of $\beta$ \\
\hline $\mathrm{Al}$ & $\mathrm{Ga}$ & 0.86 & - & $\mathrm{Ni}$ & $\mathrm{Cu}$ & 9.43 & - \\
\hline $\mathrm{Ag}$ & $\mathrm{Au}$ & $77.98 * * *$ & 0.264 & $\mathrm{Ni}$ & $\mathrm{Pd}$ & 1.37 & - \\
\hline $\mathrm{Ag}$ & $\mathrm{Cu}$ & $36.99 * * *$ & -4.668 & $\mathrm{~Pb}$ & $\mathrm{Cu}$ & 33.80 **** & 0.044 \\
\hline $\mathrm{Ag}$ & $\mathrm{Pb}$ & $30.25 * * *$ & 0.013 & $\mathrm{~Pb}$ & $\mathrm{Zn}$ & $51.90 * * *$ & -0.109 \\
\hline $\mathrm{Ag}$ & $\mathrm{Zn}$ & 7.95 & - & $\mathrm{Pb}$ & $\mathrm{Au}$ & 5.76 & - \\
\hline $\mathrm{Au}$ & $\mathrm{Ag}$ & $31.36^{* * * *}$ & 0.007 & $\mathrm{~Pb}$ & $\mathrm{Ag}$ & $58.77 * * *$ & 0.001 \\
\hline $\mathrm{Au}$ & $\mathrm{Cu}$ & $30.66 * * *$ & -0.481 & $\mathrm{~Pb}$ & $\mathrm{Sb}$ & $7.94 * *$ & 0.184 \\
\hline $\mathrm{Au}$ & $\mathrm{Zn}$ & 4.68 & - & $\mathrm{Pb}$ & $\mathrm{Bi}$ & $56.70^{* * *}$ & -0.322 \\
\hline $\mathrm{Au}$ & $\mathrm{Pb}$ & $17.70 * * *$ & -0.037 & $\mathrm{~Pb}$ & $\mathrm{Se}$ & 11.12 & - \\
\hline $\mathrm{Cu}$ & $\mathrm{Ag}$ & $29.61 * * *$ & 0.001 & $\mathrm{Pt}$ & $\mathrm{Pd}$ & 3.29 & - \\
\hline $\mathrm{Cu}$ & $\mathrm{Au}$ & $19.48 * *$ & 0.018 & $\mathrm{Pt}$ & $\mathrm{Rh}$ & 2.05 & - \\
\hline $\mathrm{Cu}$ & Mo & 15.60 & - & $\mathrm{Zn}$ & $\mathrm{Ag}$ & 1.82 & - \\
\hline $\mathrm{Cu}$ & $\mathrm{Se}$ & $43.59 * * *$ & 0.000 & $\mathrm{Zn}$ & $\mathrm{Au}$ & 0.17 & - \\
\hline $\mathrm{Cu}$ & Co & 6.40 & - & $\mathrm{Zn}$ & $\mathrm{Cd}$ & $27.87 * * *$ & 0.001 \\
\hline $\mathrm{Cu}$ & $\mathrm{Pb}$ & $54.92 * * *$ & 0.016 & $\mathrm{Zn}$ & In & 29.12 & - \\
\hline $\mathrm{Cu}$ & $\mathrm{Zn}$ & $90.58^{* * *}$ & 0.024 & $\mathrm{Zn}$ & $\mathrm{Ge}$ & 18.18 & - \\
\hline Mo & $\mathrm{Ag}$ & $258.86^{* * * *}$ & 0.000 & $\mathrm{Zn}$ & $\mathrm{Ga}$ & 31.07 & - \\
\hline Mo & $\mathrm{Au}$ & $133.38 * * *$ & 2.434 & $\mathrm{Zn}$ & $\mathrm{Cu}$ & 85.75 *** & -0.144 \\
\hline Mo & $\mathrm{Cu}$ & $58.94 * * *$ & -0.005 & $\mathrm{Zn}$ & $\mathrm{Pb}$ & $27.54 * * *$ & 0.0438 \\
\hline $\mathrm{Ni}$ & Co & 1.29 & - & & & & \\
\hline
\end{tabular}

\subsection{Joint consumption}

Our second hypothesis states that metals that share the same product should have at least a unidirectional Granger-causality in either direction, given that the market share of the metal used in that product is large enough. Based on the results in Table 6-3, 24 out of 28 metal pairs (86 \%) show significant causal links. This is much higher than the significant relationships observed in joint production. However, it is important to differentiate that we only tested for unidirectional causality for jointly produced metals whereas bidirectional causalities are tested for jointly consumed metals. Since our hypothesis for the latter case states that causality will at least be present in one direction, the metal pairs that fulfill this condition are considered significant.

In the results, causality relationships are always present among non-ferrous metal pairs. Notable results are the bidirectional causality between copper and zinc, nickel and chromium as well as between copper and tin. The causal links among non-ferrous metals can be explained by the indirect joint-consumption of wide-scale application of these metals in construction, infrastructure and transportation. A strong global economy creates additional demand for these sectors, which could lead to an increased consumption of these metals. Besides that, significant causalities are also observed among metals that are related to steel. For instance, more than $80 \%$ of the global nickel and chromium 
demand is used as an alloying element for steel, among others, stainless steel. This great concentration of usage leads to a bidirectional causality between nickel and chromium. The price of nickel is also Granger-caused by copper, which is another alloying element in steel to improve corrosion resistance. Furthermore, the price of chromium and molybdenum is Granger-caused by steel as well. Steel is traded in various forms and types, such as iron ores, pig iron or even in the form of processed steel such as rebar or scrap, which are traded on the LME. However, due to the lack of information in the data obtained from BGR, we are unable to classify the price series to an exact category of steel. Therefore, the results regarding steel in our paper should be treated with caution.

The price of gallium, which is not Granger-caused by its main primary metal aluminium, is Grangercaused by the price of arsenic, which is one of the main metals used in manufacturing semiconductors. It is, therefore, safe to conclude that the joint consumption of gallium with other metals influences its prices much stronger compared to the metals that are produced together with it. Similar results are also obtained for platinum. In the analysis of joint production, platinum does not Granger-cause any of its by-products. Similarly, platinum has absolutely no predictive power on the metal prices that are jointly consumed. However, the companion metals of platinum, namely palladium and rhodium which are used as catalytic converters in vehicles, as well as gold and silver which are used in making jewelry, Granger-causes the price of platinum. However, with the expected massive increase of electric vehicles in the future, platinum, palladium and rhodium can lose a significant share in their end-usage as catalytic converters in cars. This would lead to the weakening of the causal relationship between their prices.

Another interesting result is the absence of causality between nickel and molybdenum prices. This is owed to the time period of our analysis from 1974 to 2013. Nickel has been traded on the LME since 1979 and has since been the main global pricing mechanism for producers and consumers.

Molybdenum, however, has been traded on the LME only since 2010 and has been subject to strong price controls and speculations before that (USGS, 1999). The discrepancy in the price setting mechanism explains why we fail to identify any long-term causal links, as opposed to (Fizaine, 2015), who found a bidirectional causality between molybdenum and nickel prices from 2008 to 2013. Similarly, causality is also absent between cobalt and lithium as well as between cobalt and nickel, which are by far the largest application for cobalt in the form of $\mathrm{Li}$-ion batteries. This means that the price of cobalt is not Granger-caused by neither jointly produced nor jointly consumed metals. However, a weak causal link is detected between chromium and cobalt. Before the emergence of large-scale electric batteries and electric vehicles, superalloy was the main use of cobalt, in which a significant amount of chromium is used as well. This is the reason as to why we do not detect any causality between cobalt and lithium, which is fairly an emerging market, as opposed to the weak causal relationship between cobalt and chromium. Another reason for the lack of causality in cobalt prices is that the price of cobalt has been historically affected by determinants other than pure supply 
and demand fundamentals. For example, political unrests in Congo and Zambia, being the two of the largest cobalt producing countries in the world, as well as the determination of producer prices strongly affected the prices of cobalt (Plunkert and Jones, 1999). This explains the lack of a strong long-term causality between the price of cobalt and its companion metals, be it joint production or joint consumption.

However, a stronger causal relationship with lithium can be expected in the future, prompted by the rising demand for electric vehicles. This can already be seen at the end of 2015 when the prices of cobalt and lithium began to increase strongly (BP, 2018), as investors were trying to secure the supply of cobalt and lithium to accommodate for the boom in electric vehicles. Another type of battery that was used on a great scale before being rivaled by the Li-ion battery is the nickel-cadmium (Ni-Cd) battery. This is reflected in the bidirectional causal link between these metals. However, we assume that this relationship will weaken in time as Ni-Cd batteries are politically restricted in some parts of the world and the market for electric batteries is gradually shifting towards Li-ion batteries and nickelmetal hydride batteries, which utilize hydrogen-absorbing alloys instead of cadmium.

One would intuitively expect that metals with small market volume will not Granger-cause the price of a metal with significantly higher market volume. However, based on the results, the causality among metals seems to be independent of their market volume (see table A-3 in Appendix for the complete list of market volume of all investigated metals). For example, metals with a smaller market volume such as tin and nickel Granger-cause copper and steel respectively, which have significantly bigger market volume. A reason for this can be that the demand and price of these metals are driven by external factors, such as the global economy, which simultaneously affect the prices and create indirect relationships between these metals. This effect is detailed further in chapter 6.4 .

Table 6-3: Test statistics of the $\chi^{2}$ Wald-test for metals that are jointly consumed. $X$-> $Y$ represents the null hypothesis of $X$ does not Granger-cause $Y$, whereas $Y>X$ represents the null hypothesis of $Y$ does not Granger-cause $X . \beta$ and $\delta$ represent the corresponding sum of coefficients whenever causality is present.

* represents $10 \%$ significance level, ** 5\% significance level and *** $1 \%$ significance level.

\begin{tabular}{cccccc}
\hline$X$ & $Y$ & $\chi^{2}(X->Y)$ & Sum of $\beta$ & $\chi^{2}(Y->X)$ & Sum of $\delta$ \\
\hline $\mathrm{Ag}$ & $\mathrm{Au}$ & $77.982^{* * *}$ & 0.264 & $31.36^{* * *}$ & 0.007 \\
\hline $\mathrm{Ag}$ & $\mathrm{Cu}$ & $36.987^{* * *}$ & -4.668 & $29.612^{* * *}$ & 0.001 \\
\hline $\mathrm{Al}$ & $\mathrm{Cu}$ & 9.272 & - & $26.325^{* * *}$ & 0.025 \\
\hline $\mathrm{Cd}$ & $\mathrm{Ni}$ & $45.933^{* * *}$ & -68.510 & $46.769^{* * *}$ & 0.000 \\
\hline $\mathrm{Co}$ & $\mathrm{Li}$ & 0.674 & - & 0.307 & - \\
\hline $\mathrm{Co}$ & $\mathrm{Ni}$ & 0.856 & - & 1.286 & - \\
\hline $\mathrm{Co}$ & $\mathrm{Cr}$ & $12.253^{*}$ & 0.001 & $11.585^{*}$ & 3.016 \\
\hline $\mathrm{Cr}$ & $\mathrm{Fe}$ & $137.488^{* * *}$ & 0.003 & $71.446^{* * *}$ & 0.075 \\
\hline $\mathrm{Cu}$ & $\mathrm{Fe}$ & $77.917^{* * *}$ & 0.012 & $81.11^{* * *}$ & 1.627 \\
\hline $\mathrm{Cu}$ & $\mathrm{Zn}$ & $90.583^{* * *}$ & 0.024 & $85.753^{* * *}$ & -0.144 \\
\hline $\mathrm{Ga}$ & $\mathrm{As}$ & 0.586 & - & $7.59^{* * *}$ & -36.275 \\
\hline $\mathrm{Ga}$ & $\mathrm{Sb}$ & 0.34 & - & 2.405 & - \\
\hline $\mathrm{Ga}$ & $\mathrm{In}$ & 1.94 & - & 0.182 & - \\
\hline $\mathrm{In}$ & $\mathrm{Sn}$ & $32.701^{*}$ & 0.001 & $71.83^{* * *}$ & 0.206 \\
\hline $\mathrm{Mo}$ & $\mathrm{Ni}$ & 1.238 & - & 6.562 & - \\
\hline $\mathrm{Mo}$ & $\mathrm{Fe}$ & 3.056 & - & $54.725^{* * *}$ & 5.166 \\
\hline & & & & &
\end{tabular}




\begin{tabular}{cccccc}
\hline $\mathrm{Mo}$ & $\mathrm{Cr}$ & $16.585^{* *}$ & 0.001 & 10.391 & - \\
\hline $\mathrm{Ni}$ & $\mathrm{Fe}$ & $92.582^{* * *}$ & 0.002 & 18.251 & - \\
\hline $\mathrm{Ni}$ & $\mathrm{Cr}$ & $146.418^{* * *}$ & 0.005 & $25.08^{* *}$ & 0.058 \\
\hline $\mathrm{Ni}$ & $\mathrm{Cu}$ & 9.43 & - & $18.482^{* *}$ & 0.393 \\
\hline $\mathrm{Pt}$ & $\mathrm{Rh}$ & 2.045 & - & $16.464 * * *$ & 0.025 \\
\hline $\mathrm{Pt}$ & $\mathrm{Pd}$ & 3.286 & - & $13.809 * *$ & -0.070 \\
\hline $\mathrm{Pt}$ & $\mathrm{Au}$ & 7.525 & - & $32.362^{* * *}$ & -0.022 \\
\hline $\mathrm{Pt}$ & $\mathrm{Ag}$ & 8.897 & - & $81.188^{* * *}$ & 1.026 \\
\hline $\mathrm{Sn}$ & $\mathrm{Pb}$ & 6.539 & - & $25.675^{* * *}$ & 0.785 \\
\hline $\mathrm{Sn}$ & $\mathrm{Cu}$ & $26.627 * * *$ & 0.018 & $32.522 * * *$ & -0.110 \\
\hline $\mathrm{Zn}$ & $\mathrm{Fe}$ & $24.026 * * *$ & 0.016 & 7.632 & - \\
\hline
\end{tabular}

\subsection{Signs of the causality relationships}

In order to systematically interpret the direction of the causal relationships (according to the sum of $\beta$ or $\delta$ ), we group the metal pairs with significant causality relationships identified in chapter 6.1 and 6.2 , according to following categories.

1- Linked in production, not in consumption

2- Linked in consumption, not in production

3- Linked in production and consumption

In addition to that, the market volumes of the metals are also indicated in Table 6-4, in order to provide an insight regarding the influence of this factor on the direction of the causalities. A positive sum of $\beta$ or $\delta$ means, that a price change of a metal will push the price of the companion metal in the same direction according to the corresponding lag length whenever causality is present. A negative sum leads to the exact opposite reaction.

Table 6-4: Categorization of the metal pairs according to the involvement in joint production and joint consumption. $X->Y$ indicates a causality flowing from metal $X$ towards metal $Y$ and vice versa. Market size is denoted with A if the market volume of metal $X$ is bigger than that of metal $Y$ and the opposite is denoted as B. The complete market volume is listed in table A.3 in the Appendix. Positive relationships are denoted with "+" whereas "-" denotes negative relationships. " 0 " indicates that causality is not present whereas "na", which is only valid for metals of category 1, means that this relationship was not tested according to the first hypothesis while only account for unidirectional causalities.

\begin{tabular}{ccccccccccccc}
\hline$X$ & $Y$ & Category & $\begin{array}{c}\text { Market } \\
\text { volume }\end{array}$ & $\begin{array}{c}\text { Sum of } \beta \text { or } \delta \\
\text { for } X-Y\end{array}$ & $\begin{array}{c}\text { Sum of } \beta \text { or } \delta \\
\text { for } Y \rightarrow X\end{array}$ & $X$ & $Y$ & Category & $\begin{array}{c}\text { Market } \\
\text { volume }\end{array}$ & $\begin{array}{c}\text { Sum of } \beta \text { or } \delta \\
\text { for } X \rightarrow Y\end{array}$ & $\begin{array}{c}\text { Sum of } \beta \text { or } \delta \\
\text { for } Y \rightarrow X\end{array}$ \\
\hline $\mathrm{Ag}$ & $\mathrm{Pb}$ & 1 & $\mathrm{~A}$ & + & + & $\mathrm{Co}$ & $\mathrm{Cr}$ & 2 & $\mathrm{~B}$ & + & + \\
\hline $\mathrm{Cu}$ & $\mathrm{Pb}$ & 1 & $\mathrm{~A}$ & + & + & $\mathrm{Cr}$ & $\mathrm{Fe}$ & 2 & $\mathrm{~B}$ & + & + \\
\hline $\mathrm{Cu}$ & $\mathrm{Se}$ & 1 & $\mathrm{~A}$ & + & $\mathrm{Na}$ & $\mathrm{Cu}$ & $\mathrm{Fe}$ & 2 & $\mathrm{~B}$ & + & + \\
\hline $\mathrm{Mo}$ & $\mathrm{Ag}$ & 1 & $\mathrm{~B}$ & + & $\mathrm{Na}$ & $\mathrm{In}$ & $\mathrm{Sn}$ & 2 & $\mathrm{~A}$ & + & + \\
\hline $\mathrm{Mo}$ & $\mathrm{Au}$ & 1 & $\mathrm{~B}$ & + & $\mathrm{Na}$ & $\mathrm{Ni}$ & $\mathrm{Cr}$ & 2 & $\mathrm{~B}$ & + & + \\
\hline $\mathrm{Zn}$ & $\mathrm{Cd}$ & 1 & $\mathrm{~A}$ & + & $\mathrm{Na}$ & $\mathrm{Cu}$ & $\mathrm{Au}$ & 2 & $\mathrm{~B}$ & + & - \\
\hline $\mathrm{Pb}$ & $\mathrm{Zn}$ & 1 & $\mathrm{~B}$ & - & - & $\mathrm{Sn}$ & $\mathrm{Cu}$ & 2 & $\mathrm{~B}$ & + & + \\
\hline $\mathrm{Mo}$ & $\mathrm{Cu}$ & 1 & $\mathrm{~B}$ & - & $\mathrm{Na}$ & $\mathrm{Cd}$ & $\mathrm{Ni}$ & 2 & $\mathrm{~B}$ & - & + \\
\hline $\mathrm{Au}$ & $\mathrm{Pb}$ & 1 & $\mathrm{~A}$ & - & $\mathrm{Na}$ & $\mathrm{Al}$ & $\mathrm{Cu}$ & 2 & $\mathrm{~A}$ & 0 & + \\
\hline $\mathrm{Pb}$ & $\mathrm{Bi}$ & 1 & $\mathrm{~A}$ & - & $\mathrm{Na}$ & $\mathrm{Pt}$ & $\mathrm{Ag}$ & 2 & $\mathrm{~B}$ & 0 & + \\
\hline $\mathrm{Ag}$ & $\mathrm{Au}$ & 3 & $\mathrm{~B}$ & + & + & $\mathrm{Sn}$ & $\mathrm{Pb}$ & 2 & $\mathrm{~B}$ & 0 & + \\
\hline $\mathrm{Ag}$ & $\mathrm{Cu}$ & 3 & $\mathrm{~B}$ & - & + & $\mathrm{Mo}$ & $\mathrm{Fe}$ & 2 & $\mathrm{~B}$ & 0 & + \\
\hline $\mathrm{Cu}$ & $\mathrm{Zn}$ & 3 & $\mathrm{~A}$ & + & - & $\mathrm{Mo}$ & $\mathrm{Cr}$ & 2 & $\mathrm{~B}$ & + & 0 \\
\hline $\mathrm{Pb}$ & $\mathrm{Sb}$ & 3 & $\mathrm{~A}$ & + & 0 & $\mathrm{Ni}$ & $\mathrm{Fe}$ & 2 & $\mathrm{~B}$ & + & 0 \\
\hline $\mathrm{Ni}$ & $\mathrm{Cu}$ & 3 & $\mathrm{~B}$ & 0 & + & $\mathrm{Zn}$ & $\mathrm{Fe}$ & 2 & $\mathrm{~B}$ & + & 0 \\
\hline $\mathrm{Pt}$ & $\mathrm{Rh}$ & 3 & $\mathrm{~A}$ & 0 & + & $\mathrm{Ga}$ & $\mathrm{As}$ & 2 & $\mathrm{~A}$ & 0 & - \\
\hline $\mathrm{Pt}$ & $\mathrm{Pd}$ & 3 & $\mathrm{~A}$ & 0 & - & $\mathrm{Pt}$ & $\mathrm{Au}$ & 2 & $\mathrm{~B}$ & 0 & - \\
\hline
\end{tabular}




\section{Category 1}

Mixed results are observed for metal pairs of this category as 6 pairs show positive causality relationship whereas 7 metal pairs have negative relationships. All negative relationships occur when a co-product Granger-causes it's primary metal, with the exception of lead-bismuth. This is true for all co-products except for silver-lead, which happens to be the primary metal and co-product of each other simultaneously. Interestingly, all of the co-products that negatively Granger-cause the prices of their respective primary metals have higher average prices (see Table 3 for comparison of mean prices). This is even true if the market volume of the co-product is much smaller than that of the primary metal. The price movements in the opposite directions (negative relationship) can be caused by the overproduction of a metal due to the increased demand for its companion metal. For example, as the price of molybdenum increases, mine owners will increase the production of copper ores.

Consequently, this will cause an oversupply of copper, assuming that the demand remains unchanged, and ultimately decreasing the copper price. Under this circumstance, we assume that, since the price of molybdenum is much higher than copper, producers react much faster to alter the production strategy in case of a demand surge for molybdenum, thus amplifying the frequency of an oversupply of copper.

On the other hand, positive relationships can be explained by two main factors. Firstly, the demands of both metals increase simultaneously, which does not create an oversupply of any metals. Secondly, the additional volume of the jointly-produced metals does not enter the market since they are either stored or disposed of, given that the volume is too small or the operational costs of the companion metals are not justified by the market prices. Consequently, this prevents the surplus of the companion products, which does not alter the price relationship between the metals. Moreover, Afflerbach et al. (2014) discussed that the additional production of the primary metal due to increased demand can increase the marginal costs, thus decreasing the profit margin of the primary metal. Therefore, it is also of the interest of mine operators, that the supply of companion metals to be strictly controlled since they are required to bring in additional profits in order to compensate the profit losses experienced by the primary metals. One of the ways of achieving this, apart from storing, is to relocate the mining activity to a different area within a mine. As discussed by Jordan (2017), the geographical distribution of various ore-grades in a mine provides mine operators with the flexibility to conduct a targeted mining in a certain area so that the demand and supply of other companion metals remain unchanged.

Considering all aspects, our results show that metals can behave as both complements and substitutes in production. On top of that, our results also show that in case of a significant Granger-causal link between metal prices, there is a strong tendency for co-products to have an inversely related relationship with their primary metals. For by-products, no clear trend can be identified. 


\section{Category 2}

$80 \%$ of the significant metal pairs under category 2 have a positive relationship, which means that the prices of jointly-consumed metals in specific products generally tend to move in the same direction in case of significant causal links. This supports our hypothesis that a change in demand for a product affects the demand and prices of all involved metals simultaneously, causing them to behave as complements. This effect will be further amplified if the particular product has a high rate of recycling, as this would reinforce the dependency of the jointly-consumed metals. The indirect joint-production, in the form of product recycling, will ensure a more stable supply and that the related metals are less susceptible to external price shocks.

There are two possible explanations for the negative relationships between metals in this category. Firstly, as described by Tilton and Guzmán (2016), a decrease in the price of a metal will increase the price of its companion metal due to the dependency to the demand of the product. For example, the fall in gold prices may stimulate the demand for jewelry and subsequently for platinum or the cheaper prices of arsenic might push the demand for gallium-arsenic semiconductors. Assuming that the production of platinum or gallium cannot be changed fast enough to accommodate the increased demand, their prices will increase, until market equilibrium is reached. Secondly, negative signs can occur as a result of the substitution of the product itself, in which both metals are applied. For instance, a sudden surge of nickel will decrease the demand for Ni-Cd batteries, as other alternatives such as $\mathrm{Pb}$ acid or Li-ion batteries will be preferred. This creates a surplus of cadmium in the market, thus lowering its price. Although we did select jointly-consumed metals that are not easily substitutable, we could not prevent the substitution effect at higher levels of consumption aggregation. This is clearly a limit of our methodology that only focuses on a single level of aggregation.

\section{Category 3}

Metal pairs in category 3 should hypothetically exhibit positive signs since a change in supply will alter the demand simultaneously and vice versa. For instance, platinum and rhodium are mined together and are used as catalytic converters. An increase in demand for vehicles will consequently increase the demand for both metals. Therefore, an increased production in platinum mine will not lead to the oversupply of rhodium, since its demand increases as well, thus moving the price of both metals in a similar direction. However, metals in this category can also have ambiguously signaled relationships if the aforementioned reasons for a negative relationship are present and overwhelm the equilibrium provided by the simultaneous joint-production and consumption. Based on our results, $70 \%$ of the metal pairs in this category have a positive relationship, which indicates a slight tendency towards our hypothesis. 


\subsection{Robustness test}

In the following sections, we validate the robustness of our empirical results by addressing the issue of misclassification of metal pairs as well as by conducting a placebo test.

\subsubsection{Misclassification of metal-pairs}

In order to test the misclassification of the metals in terms of joint production, we set the cut-off point to $0 \%$ while complementing our metal-pairs with the wheel of companionability by (Nassar et al., 2015) to include more jointly produced metals in our analysis. We obtain 12 additional metal-pairs, as listed in Table A-4 (in Appendix). Results of the sensitivity analysis show that 9 metal pairs have significant causality relationships. Including these metal pairs in our hypothesis testing would slightly improve the amount of significant relationship from 59\% to 63\%. Since this increase is relatively small, we conclude that misclassification of metal pairs in terms of joint-production is not crucial and does not affect our results. In terms of joint consumption, the cut-off point is reduced from $30 \%$ to $10 \%$, which provided 20 additional metal pairs. A complete removal of the cut-off point in joint consumption is avoided since this would mean that every field of consumption, including niche applications, has to be included in the analysis, which might dilute the explanatory power of our results. Of the 20 metal pairs, 18 pairs have a causal link at least in one direction (see Table A-5 in Appendix). Including these metal pairs in the initial hypothesis testing would lead to a similar share of metal pairs with causality relationships. In consequence, the error due to misclassification is not significant since similar results are obtained in the sensitivity analysis.

\subsubsection{Placebo test}

We assume that the results presented in this paper are robust since we apply the Toda-Yamamoto approach, which reduces spurious results and ensures the validity of the asymptotic distribution theory of the bivariate VAR models. Furthermore, we even tested and eliminated any serial autocorrelations in our residuals and ensured that the VAR models are well specified. Nonetheless, in order to further ensure the robustness of our results, we follow the method applied by (Afflerbach et al., 2014), in which the authors used their methodology of linear regression to every possible combination of data that were available. Hypothetically, these metal pairs are "randomly" selected. We apply the TodaYamamoto approach to test for Granger-causality for every other metal pairs that we have not tested under the premise of joint production and joint consumption. The hypothesis of our robustness test is that the number of causal relationships among random metal pairs should be lower compared to the metals pairs that are jointly consumed or produced. Based on the results in Table A.3 (Appendix), it can be seen that only $30 \%$ of the metal pairs exhibit causal relationship, which is clearly lower than our main results and is in line with our hypothesis of the placebo test. This reassures that the results are not spurious and that the methodology applied is robust and not biased. 
The question remains, as to why is there still a considerable amount of causal relationship among metals in the placebo test. One plausible explanation for this is the effect of indirect joint-consumption, which can occur through the dependencies of the metal prices on external macroeconomic factors. This has been previously proved by Labys et al. (1999), who identified that the industrial production is a strong common factor that influences metal prices. Besides that, similar results were also reported by Klotz et al. (2014), who tested the causality relationship between commodity prices, including industrial and precious metals, and macroeconomic factors. The authors found significant causalities between metal prices and economic activity as well as the real interest rate. This, for example, explains the causal relationship between zinc and aluminium. Although we cannot classify both metals down to a specific product, they are mostly used in constructions in the form of various products. An economic prosperity would mean stronger investment activities, through which the construction sector will boom, increasing the demand of both metals together. Another possibility of indirect joint-consumption is contributed by the common field of application at a higher level of demand aggregation. In our analysis, we only focus on the use of metals in a similar product, such as the use of lithium, nickel and cobalt in Li-ion batteries. However, if the product itself is usually used together with other products, an indirect relationship might exist. For example, Li-ion batteries (such as NMC or NCA batteries) are used as stationary home storages together with rooftop PV systems. This indirect joint-consumption may lead to the causality that is observed between Co and Ag, although both metals are not related according to our definition and methodology. Another example is the relationship between cobalt, lithium and platinum group elements (PGE). While lithium and cobalt are found in batteries in electric vehicles (EV), PGEs are used as catalytic converters in conventional cars. Although they are in separate products, they might behave as substitutes as EVs are gradually taking over the market share of conventional vehicles, thus increasing the need for batteries while reducing the demand for catalytic converters. Once again, these examples are clearly a result of the limitations to our methodology, which only focus on the common use of metals in end-products. The placebo test indicates that there might be also significant relationships at higher levels of aggregation.

\section{Conclusion and further works}

This paper aimed at analyzing the long-term causal relationship between metals that are jointly produced and jointly consumed. We applied the Toda-Yamamoto approach of Granger-causality and used a large number of samples in the form of real monthly prices in our analysis. In order to test the causal relationships systematically, we proposed two hypotheses and set up our models to test them.

The first hypothesis states that a primary metal Granger-causes the prices of its co- and by-products, whereas co-products Granger-causes the prices of primary metal and other co-products. Empirical results indicate that primary metals and co-products tend to Granger-cause each other. Besides that, 
significant causal relationships among co-products of their respective primary metals also exist. We observed that in case of the presence of Granger-causality, co-products move the price of primary metals in the opposite direction, given that the co-products have higher prices compared to the primary metals. Meanwhile, no general statement can be made regarding the causality of by-products as mixed results were obtained. Therefore, we conclude that the joint production of primary metals and their coproducts is a strong determinant that affects their prices and that this relationship should definitely be considered while making any anticipation regarding price movements. In terms of by-products, we highly recommend individual consideration of the metals due to the absence of a general trend.

The second hypothesis states that causality is present among metals that are jointly consumed. Based on the results, we found this hypothesis to be true. We found evidence that the Granger-causality among metals due to joint consumption predominantly causes the metal prices to move in a similar direction, which means that a demand shock of a product of an application field affects the metal demand collectively in most instances. Nonetheless, our results for joint-consumption of metals are strongly limited by the choice of metal-pairs, which is chosen based on the common use in a product. The robustness test indicates that a considerable amount of causality still exists beyond our definition in this paper which is caused by the indirect joint-consumption at a higher level of demand aggregation or the dependency to external macroeconomic factors. Therefore, as further works, we highly recommend analysis of price dependencies of a much smaller batch of jointly-consumed metals, for which the consumption structure and their corresponding effect on price dependency at various aggregation levels can be analyzed in detail. Furthermore, the changing consumption structures of metals should be considered as the relationship between metals evolves over time based on their field of application and the corresponding companion metals.

All things considered, the main conclusion based on our results is that the joint consumption of metals has a strong tendency to affect the prices of related metals. In fact, metals that are jointly consumed possess relatively stronger predictive power among themselves compared to metals produced together. Therefore, as policy recommendations, we propose that policy makers strongly consider the effects of both joint-production and joint-consumption of metals when proposing policies related to metal prices. The joint-production effects of metals should be considered when assessing the criticality of a metal, especially in terms of supply risk since the physical availability of metals, particularly of co-products, are very much depended on its companion metals. Stronger policies to ensure a higher rate of recycling for jointly-consumed metals with a large market share in an end-use product is necessary as this will ensure a more stable supply of metals. In the long-run, joint-consumption of metals will eventually lead to a joint-production via a functional closed-loop recycling process, thus limiting the impact of price fluctuations of the companion metals. Last but not least, the changing demand structures involving emerging technologies should also be considered when creating policies involving metal prices and supply, as they will have a stronger impact on price dependencies in the future. 


\section{References}

Afflerbach, P., Fridgen, G., Keller, R., Rathgeber, A.W., Strobel, F., 2014. The by-product effect on metal markets - New insights to the price behavior of minor metals. Resources Policy 42, 35-44.

Alimi, S.R., Ofonyelu, C.C., 2013. Toda-Yamamoto Causality Test Between Money Market, Interest Rate and Expected Inflation: The Fischer Hypothesis Revisited. European Scientific Journal 9 (7), 125-142.

Arepo Solutions Ltd, 2018. ILZSG - End Uses of Zinc. International Lead and Zinc Study Group. <http://www.ilzsg.org/static/enduses.aspx?from=1> (accessed 6/28/2018).

Ayres, R.U., Ayres, L.W., Råde, I., 2003. The Life Cycle of Copper, Its Co-Products and Byproducts. Springer, Dordrecht, 265 pp.

Basoglu, M.S., Korkmaz, T., Cevik, E.I., 2014. London Metal Exchange: Causality Relationship between the Price Series of Non-Ferrous Metal Contracts. International Journal of Economics and Financial Issues 4 (4), 726-734.

Binder, C.R., Graedel, T.E., Reck, B., 2006. Explanatory Variables for per Capita Stocks and Flows of Copper and Zinc. Journal of Industrial Ecology 10 (1-2), 111-132.

BP, 2018. BP Statistical Review of World Energy, London.

Breusch, T.S., 1978. Testing for Autocorrelation in Dynamic Linear Models. Australian Economic Papers 17 (31), 334-355.

Brooks, D.B., 1965. Supply and Competition in Minor Metals. RFF Press, Abingdon, Oxon, New York, NY, 1 online resource.

Buti, M., Sapir, A. (Eds.), 1998. Economic policy in EMU: A study by the European Commission services. Clarendon Press, Oxford, $256 \mathrm{pp}$.

Campbell, G.A., 1985. The role of co-products in stabilizing the metal mining industry. Resources Policy 11 (4), 267-274.

Chaido Dritsaki, 2017. Toda-Yamamoto Causality Test between Inflation and Nominal Interest Rates: Evidence from Three Countries of Europe. International Journal of Economics and Financial 7 (6), 120-129.

Chan, M.W.L., Mountain, C., 1988. The Interactive and Causal Relationships Involving Precious Metal Price Movements: An Analysis of the Gold and Silver Markets. Journal of Business \& Economic Statistics 6 (1), 69.

Chowdhury, A.R., 1987. Are causal relationships sensitive to causality tests? Applied Economics 19 (4), 459-465.

Ciner, C., 2001. On the long run relationship between gold and silver prices A note. Global Finance Journal 12 (2), 299-303.

Consolidated Tin Mines Ltd., 2018. Global Tin Market. <http://www.csdtin.com.au/?page_id=183> (accessed 6/28/2018).

Coronado, S., Fullerton, T.M., Rojas, O., 2016. Causality patterns for Brent, WTI, and Argus oil prices. Applied Economics Letters 24 (14), 982-986.

CPA Australia, 2012. Guide to managing commodity risk. CPA Australia Ltd, Southbank, Victoria.

Dickey, D.A., Fuller, W.A., 1979. Distribution of the Estimators for Autoregressive Time Series with a Unit Root. Journal of the American Statistical Association 74 (366), 427-431.

Donachie, M.J., Donachie, S.J., 2008. Superalloys: A technical guide, 2. ed., 3. printing. ASM Internat, Materials Park, OH, x, 439 Seiten.

Doran, H.E., Rambaldi, A.N., 1997. Applying linear time-varying constraints to econometric models: With an application to demand systems. Journal of Econometrics 79 (1), 83-95. 
Engle, R.F., Granger, C.W.J., 1987. Co-Integration and Error Correction: Representation, Estimation, and Testing. Econometrica 55 (2), 251-276.

Fizaine, F., 2013. Byproduct production of minor metals: Threat or opportunity for the development of clean technologies? The PV sector as an illustration. Resources Policy 38 (3), 373-383.

Fizaine, F., 2015. Minor metals and organized markets: News highlights about the consequences of establishing a futures market in a thin market with a dual trading price system. Resources Policy 46, 59-70.

Frankel, J.A., 1986. Expectations and Commodity Price Dynamics: The Overshooting Model. American Journal of Agricultural Economics 68 (2), 344.

Geibig J.R., Socolof M.L., 2005. Solders in Electronics: Solders in Electronics: A Life-Cycle Assessment. University of Tennessee Center. <https://www.epa.gov/sites/production/files/201312/documents/lead_free_solder_Ica_summary.pdf $>$.

GEMC, 2018. Cobalt Demand: Cobalt's End Market. Global Energy Metals Corp. $<$ https://www.globalenergymetals.com/cobalt/cobalt-demand/> (accessed 5/2/2018).

Ghosh, D., Levin, E., Macmillan, P., Wright, R.E., 2004. Gold as an inflation hedge? Studies in Economics \& Finance 22 (1), 1-25.

Ghosh, S., 2006. Steel consumption and economic growth: Evidence from India. Resources Policy 31 (1), 7-11.

Giles, D.E.A., 1997. Causality between the measured and underground economies in New Zealand. Applied Economics Letters 4 (1), 63-67.

Glencore, 2017. Nickel: State of the Market. 33rd International Ferroalloys Conference, Lisbon. <http://www.glencore.com/investors/speeches-and-presentation>.

Godfrey, L.G., 1978. Testing for Higher Order Serial Correlation in Regression Equations when the Regressors Include Lagged Dependent Variables. Econometrica 46 (6), 1303.

Granger, C.W.J., 1969. Investigating Causal Relations by Econometric Models and Cross-spectral Methods. Econometrica 37 (3), 424.

Hacker, R.S., Hatemi-J, A., 2006. Tests for causality between integrated variables using asymptotic and bootstrap distributions: Theory and application. Applied Economics 38 (13), 1489-1500.

Hagelüken, C., Meskers, C.E.M., 2010. Complex Life Cycles of Precious and Special Metals, in: Graedel, T.E., van der Voet, E. (Eds.), Linkages of sustainability. MIT Press, Cambridge, Mass., pp. 163-197.

Hecht, J., 2001. Understanding lasers: An entry-level guide, Second edition. IEEE; Wiley-Interscience, New York, 1 online resource ( $x x, 422$.

Huang Z., Martin F., 2017. Selection of a Portfolio of Pairs Based on Cointegration: A Statistical Arbitrage Strategy. Working Paper halshs-01566803. University of Rennes; University of Caen Normamdie. <https://halshs.archives-ouvertes.fr/halshs-01566803>.

Hustrulid, W.A., Bullock, R.L., 2001. Underground mining methods: Engineering fundamentals and international case studies. Society for Mining, Metallurgy and Exploration, Littleton, Colorado, $x$, 718.

ICSG, 2017. The World Copper Factbook 2017. International Copper Study Group, Lisbon. <http://www.icsg.org/index.php/component/jdownloads/finish/170/2462>.

Imgrund, H., Kinsman, N., 2007. Molybdenum - an extraordinary metal in high demand. International Molybdenum Association, Brussels.

<https://www.imoa.info/download_files/molybdenum/Molybdenum.pdf>.

ITRPV, 2018. International Technology Roadmap for Photovoltaic: 2017 Results.

IWCC, ICA, 2017. Global 2018 Semis End Use Data Set. International Wrought Copper Council; International Copper Association. 
Jain, A., Ghosh, S., 2013. Dynamics of global oil prices, exchange rate and precious metal prices in India. Resources Policy 38 (1), 88-93.

Jerrett, D., Cuddington, J.T., 2008. Broadening the statistical search for metal price super cycles to steel and related metals. Resources Policy 33 (4), 188-195.

Johansen, S., 1991. Estimation and Hypothesis Testing of Cointegration Vectors in Gaussian Vector Autoregressive Models. Econometrica 59 (6), 1551.

John Sykes, 2012. Supply shortages in tin mining supply and its effect on the global electronics industry. Greenfields Research Ltd; ITRI Ltd., Guangzhou.

Jordan, B., 2018. Economics literature on joint production of minerals: A survey. Resources Policy 55, 20-28.

Jordan, B.W., 2017. Companions and competitors: Joint metal-supply relationships in gold, silver, copper, lead and zinc mines. Resource and Energy Economics 49, 233-250.

Kim, H., Gilmore, C.M., Piqué, A., Horwitz, J.S., Mattoussi, H., Murata, H., Kafafi, Z.H., Chrisey, D.B., 1999. Electrical, optical, and structural properties of indium-tin-oxide thin films for organic lightemitting devices. Journal of Applied Physics 86 (11), 6451-6461.

Kim, H., Heo, E., 2012. Causality Between Main Product and Byproduct Prices of Metals Used for Thin-Film PV Cells. IAEE Asia, Seoul, 9 pp. (accessed 5/11/2018).

Klotz, P., Lin, T.C., Hsu, S.-H., 2014. Global commodity prices, economic activity and monetary policy: The relevance of China. Resources Policy 42, 1-9.

Krausmann, F., Gingrich, S., Eisenmenger, N., Erb, K.-H., Haberl, H., Fischer-Kowalski, M., 2009. Growth in global materials use, GDP and population during the 20th century. Ecological Economics 68 (10), 2696-2705.

Krawiec, M., Górska Anna, 2015. Granger Causality Tests For Precious Metal Returns. Metody llościowe w Badaniach Ekonomicznych XVI (2), 13-22.

Kwiatkowski, D., Phillips, P.C.B., Schmidt, P., Shin, Y., 1992. Testing the null hypothesis of stationarity against the alternative of a unit root. Journal of Econometrics 54 (1-3), 159-178.

Labys, W.C., Achouch, A., Terraza, M., 1999. Metal prices and the business cycle. Resources Policy 25 (4), 229-238.

Lattin, J.M., McAlister, L., 1985. Using a Variety-Seeking Model to Identify Substitute and Complementary Relationships among Competing Products. Journal of Marketing Research 22 (3), 330.

Lokanc, M., Eggert, R., Redlinger, M., 2015. The Availability of Indium: The Present, Medium Term, and Long Term. United States. Office of the Assistant Secretary of Energy Efficiency and Renewable Energy.

Lunk, H.-J., 2015. Discovery, properties and applications of chromium and its compounds. ChemTexts, $1-6$.

Lütkepohl, H., 1982. Non-causality due to omitted variables. Journal of Econometrics 19 (2-3), 367378.

Lutzenberger, F., Gleich, B., Mayer, H.G., Stepanek, C., Rathgeber, A.W., 2017. Metals: Resources or financial assets? A multivariate cross-sectional analysis. Empirical Economics 53 (3), 927-958.

Mishra, P.K., 2014. Gold Price and Capital Market Movement in India: The Toda-Yamamoto Approach. Global Business Review 15 (1), 37-45.

Mohr, S., Giurco, D., Retamal, M., Mason, L., Mudd, G., 2018. Global Projection of Lead-Zinc Supply from Known Resources. Resources 7 (1), 17.

Mordor Intelligence, 2018. Global Tin Market - Segmented by Product Type, Application, End-user Industry and Geography - Growth, Trends and Forecast (2018 - 2023), 135 pp. 
Nassar, N.T., Graedel, T.E., Harper, E.M., 2015. By-product metals are technologically essential but have problematic supply. Science advances 1 (3), e1400180.

Nazlioglu, S., Soytas, U., 2011. World oil prices and agricultural commodity prices: Evidence from an emerging market. Energy Economics 33 (3), 488-496.

Neill Fortune, J., 1987. The inflation rate of the price of gold, expected prices and interest rates. Journal of Macroeconomics 9 (1), 71-82.

Nordelöf, A., Grunditz, E., Tillman, A.-M., Thiringer, T., Alatalo, M., 2018. A scalable life cycle inventory of an electrical automotive traction machine-Part I: Design and composition. Int J Life Cycle Assess 23 (1), 55-69.

Oxford, 2018. Platinum Quarterly: Q1 2018. World Platinum Investment Council Ltd. <https://www.platinuminvestment.com/files/853874/WPIC_Platinum_Quarterly_Q1_2018.pdf>.

Palisade Research, 2016. A Brief Cobalt Primer. Palisade Research. <https://palisaderesearch.com/wp-content/uploads/2016/10/2016.10.26-Palisade-Research-Cobalt-Final.pdf> (accessed 5/2/2018).

Plachy, J., 2000. Cadmium. U.S. Geological Survey Minerals Yearbook, 16.1 - 16.7.

Plunkert, P.A., Jones, T.S., 1999. Metal Prices in the United States through 1998.

Pradhananga, M., 2016. Financialization and the rise in co-movement of commodity prices. International Review of Applied Economics 30 (5), 547-566.

Rankin, W.J., 2011. Minerals, Metals and Sustainability: Meeting future material needs. CRC Press, Leiden, Netherlands, xvi, 419.

Redlinger, M., Eggert, R., 2016. Volatility of by-product metal and mineral prices. Resources Policy 47, 69-77.

Risopatron, C., 2014. Developments and New Challenges for Base Metals: The Case of Copper, Zinc, Lead and Nickel, in: . Multi-year Expert Meeting on Commoditites and Development, Geneva. 910 April.

Roberts, D.L., Nord, S., 2006. Causality tests and functional form sensitivity. Applied Economics 17 (1), 135-141.

Roskill, 2014. Gallium: Global industry markets and outlook, 9. ed. Roskill Information Services, London, $121 \mathrm{~S}$.

Rossen, A., 2015. What are metal prices like?: Co-movement, price cycles and long-run trends. Resources Policy 45, 255-276.

Saga, T., 2010. Advances in crystalline silicon solar cell technology for industrial mass production. NPG Asia Materials 2 (3), 96-102.

Schwarz, G., 1978. Estimating the Dimension of a Model. The Annals of Statistics 6 (2), 461-464.

Shields, J.A., 2013. Application of Molybdenum Metal and its Alloys, 2nd. International Molybdenum Association (IMOA), London.

Sims, C.A., 1980. Macroeconomics and Reality. Econometrica 48 (1), 1.

Śmiech, S., Papież, M., 2012. A dynamic analysis of causality between prices on the metals market, in: Proceedings of the International Scientific Conference "Quantitative Methods in Economics". Multiple Criteria Decision Making XVI", Bratislava, Slovakia, 30th May-1st June 2012. Vydavatel'stvo EKONÓM, Bratislava, pp. 221-225.

Stern, D.I., 2011. From Correlation to Granger Causality. Crawford School Research Paper No. 13. Thomson Reuters, The Silver Institute, 2018. World Silver Survey 2018, London.

Tilton, J.E., Guzmán, J.I., 2016. Mineral economics and policy. RFF Press Resources for the future, Abingdon, xiv, 255 Seiten. 
Toda, H.Y., Yamamoto, T., 1995. Statistical inference in vector autoregressions with possibly integrated processes. Journal of Econometrics 66 (1-2), 225-250.

Tsujikawa, M., Egawa, M., Ueda, N., Okamoto, A., Sone, T., Nakata, K., 2008. Effect of molybdenum and copper on S-phase layer thickness of low-temperature carburized austenitic stainless steel. Surface and Coatings Technology 202 (22-23), 5488-5492.

USGS, 1999. Metal Prices in the United States Through 1998. U.S. Geological Survey.

USGS, 2018. Mineral Commodity Summaries 2018. U.S. Geological Survey, Virginia:

Wolde-Rufael, Y., 2006. Electricity consumption and economic growth: A time series experience for 17 African countries. Energy Policy 34 (10), 1106-1114.

World Gold Council, 2018. Gold Demand Sectors. <https://www.gold.org/about-gold/golddemand/sectors-of-demand> (accessed 5/2/2018).

Yakubu, Y., Abdul Jalil, S., 2016. Modified Wald Test Approach into Causality between Electricity and Manufacturing Sector in Nigeria. IOSR Journal of Economics and Finance 7 (1), 47-61. 